\title{
Half-Sandwich Rare Earth Metal Catalysts for Olefin Polymerization and Copolymerization
}

\author{
Zhaomin Hou \\ Organometallic Chemistry Laboratory, RIKEN (The Institute of Physical and Chemical \\ Research), and PRESTO, \\ Japan Science and Technology Agency (JST), Japan
}

Received July 20, 2005

\begin{abstract}
This article describes the synthesis and polymerization catalysis of rare earth metal bis(alkyl) complexes bearing mono(cyclopentadienyl) ligands. Polymerization and copolymerization of ethylene, 1-hexene, styrene, norbornene, dicyclopentadiene, 1,3-hexadiene, cyclohexene oxide, and carbon dioxide are reported. Many of these reactions show unprecedented regio- and stereoselectivity, and afford a series of new polymers that were difficult to be prepared previously by other catalysts.
\end{abstract}

\section{Introduction}

The development of homogeneous, single-site polymerization catalysts has opened a new avenue in the synthesis of polymer materials with controlled microstructures and desired properties. Changing the ligand environment or the central metal ion of a metal complex to modify its properties is an important strategy for the development of more efficient or selective catalysts. Compared to most d-block transition metals which can show variable (different) oxidation states, rare earth metals usually adopt the +3 oxidation state as the most stable oxidation state, which is not easily changed to other oxidation states under normal conditions. This nature of the oxidation state makes rare earth metals unique candidates for the architecture of true "single-site" polymerization catalysts. However, most of the rare earth metal (Ln) catalysts reported so far were mainly based on monoalkyl or monohydride Ln(III) complexes or Sm(II) complexes, which bear two bulky anionic ancillary ligands (e.g., substituted cyclopentadienyl groups). ${ }^{1}$ Although such complexes are active for the polymerization of ethylene or polar monomers without requirement of a cocatalyst, they usually show no or low activity for higher olefins such styrene, 1-alkenes, cyclic olefins, and dienes, because of the steric hindrance of the two sterically demanding ancillary ligands. Recently, considerable attention has been directed to bis(alkyl) and dihydride complexes bearing one anionic ancillary ligand, ${ }^{2,3}$ since such complexes are expected to provide a sterically and electronically more unsaturated metal center and thus to show unique reactivities that differ from those of the conventional metallocenes. This account is focused on the polymerization chemistry of the rare earth metal bis(alkyl) complexes bearing one cyclopentadienyl group as an ancillary ligand. Such half-sandwich rare earth metal complexes showed unprecedented activity and selectivity in the polymerization and copolymerization of various olefins.

\section{Synthesis of Half-Sandwich Rare Earth Metal Bis(alkyl) Complexes}

The isolation of a half-sandwich rare earth metal bis(alkyl) complex bearing one cyclopentadienyl ligand is generally much more difficult than that of a mono(alkyl) complex with two cyclopentadienyl ligands, because of ligand redistribution problems. An appropriate metal/ligand combination is rather critical. In the case of scandium, which is the smallest one in ion size in the rare earth series, the bis(trimethylsilymethyl) complexes bearing different cyclopentadienyl ligands, such as [Cp' $\mathrm{Sc}\left(\mathrm{CH}_{2} \mathrm{SiMe}_{3}\right)_{2}$ (thf)] $(\mathrm{Cp}$ ' = $\mathrm{C}_{5} \mathrm{Me}_{4} \mathrm{SiMe}_{3}(\mathbf{1}), \mathrm{C}_{5} \mathrm{H}_{3}\left(\mathrm{SiMe}_{3}\right)_{2}-1,3$ (2), $\mathrm{C}_{5} \mathrm{Me}_{5}(\mathbf{3})$ ), have been prepared by the acid-base reaction between the scandium tris(alkyl) complex $\left[\mathrm{Sc}\left(\mathrm{CH}_{2} \mathrm{SiMe}_{3}\right)_{3}(\mathrm{thf})_{2}\right]$ and one equivalent of the cyclopentadiene ligands $\mathrm{Cp}$ 'H (Scheme 1). ${ }^{4}$ For larger rare earth metal ions, the corresponding bis(alkyl) complexes bearing the $\left[\mathrm{C}_{5} \mathrm{Me}_{4} \mathrm{SiMe}_{3}\right]^{-}$ligand, $\left[\left(\mathrm{C}_{5} \mathrm{Me}_{4} \mathrm{SiMe}_{3}\right) \mathrm{Ln}\right.$ $\left.\left(\mathrm{CH}_{2} \mathrm{SiMe}_{3}\right)_{2}(\mathrm{thf})\right](\mathrm{Ln}=\mathrm{Y}(\mathbf{4}), \mathrm{Gd}(5)$, Dy (6), Ho (7), Er (8), $\operatorname{Tm}(\mathbf{9}), \mathrm{Lu}(\mathbf{1 0}))$, can be obtained in an analogous way (Scheme 2). ${ }^{5}$ However, when less sterically demanding ligands such as $\mathrm{C}_{5} \mathrm{H}_{3}\left(\mathrm{SiMe}_{3}\right)_{2}-1,3, \mathrm{C}_{5} \mathrm{Me}_{5}$, or $\mathrm{C}_{5} \mathrm{H}_{5}$ are used for these metals, a mixture of mono(cyclopentadienyl)-coordinated and bis(cyclopentadienyl)-coordinated complexes is usually formed. Complexes 1-10 have all been structurally characterized by $\mathrm{X}$-ray crystallographic studies. The $\mathrm{X}$-ray structure of the scandium complex $\mathbf{1}$ is shown in Figure 1. These complexes are all soluble in common organic solvents, such as hexane, toluene, and THF. Ligand redistribution is not observed in solution, but in some cases thermal decomposition of the alkyl species takes place, and therefore their stor-

Scheme 1. Synthesis of scandium bis(alkyl) complexes bearing mono(cyclopentadienyl) ligands

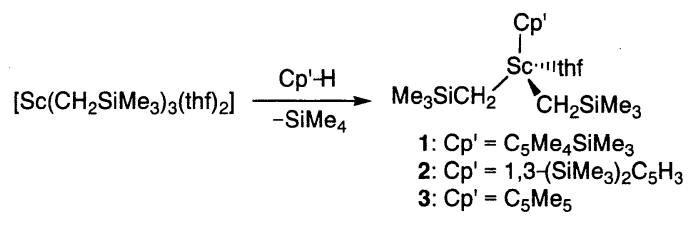

Scheme 2. Synthesis of rare earth metal bis(alkyl) complexes bearing the $\mathrm{C}_{5} \mathrm{Me}_{4} \mathrm{SiMe}_{3}$ ligand

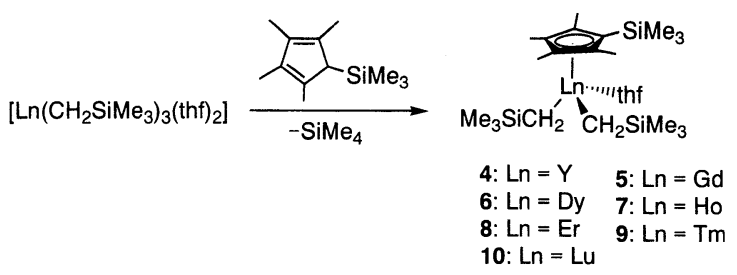




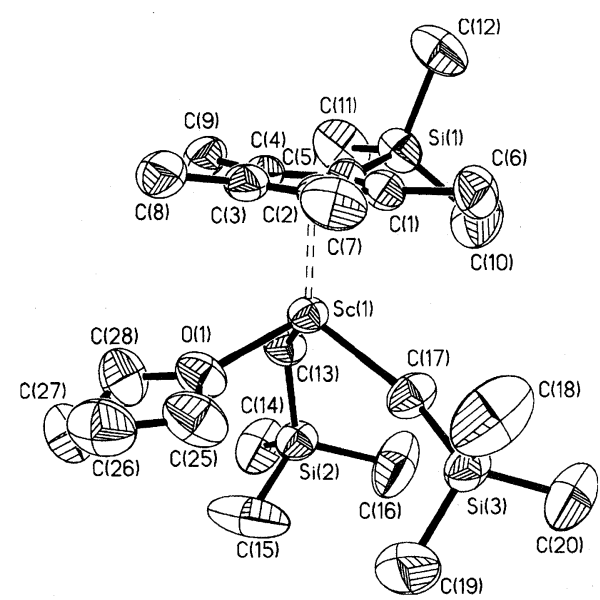

Figure 1. ORTEP drawing of $\mathbf{1}$.

age at low temperatures is requisite.

\section{Polymerization and Copolymerization of Ethylene, Styrene, and 1-Hexene}

\subsection{Syndiospecific, Living Polymerization of Styrene}

The neutral half-sandwich rare earth metal bis(alkyl) complexes $\left(\mathrm{C}_{5} \mathrm{Me}_{4} \mathrm{SiMe}_{3}\right) \mathrm{Ln}\left(\mathrm{CH}_{2} \mathrm{SiMe}_{3}\right)_{2}(\mathrm{thf})$ alone did not show activity for styrene polymerization at room temperature in toluene. When treated with 1 equiv of $\left[\mathrm{Ph}_{3} \mathrm{C}\right]\left[\mathrm{B}\left(\mathrm{C}_{6} \mathrm{~F}_{5}\right)_{4}\right]$, however, all of these complexes became active for the syndiospecific polymerization of styrene, with the activity being dependent on both the ion size of the central metals and the ancillary ligands. Some representative results are summarized in Table 1. Among the scandium complexes 1-3, the $\left(\mathrm{C}_{5} \mathrm{Me}_{4} \mathrm{SiMe}_{3}\right)$-ligated complex 1 showed the highest activity (up to $1.36 \times 10^{4} \mathrm{~kg} /(\mathrm{mol}-\mathrm{Sc} \cdot \mathrm{h})$ ), ${ }^{4 a}$ which can be compared with the most active catalysts ever reported for syndiospecific styrene polymerization. ${ }^{6-9}$ The true active species in the present catalyst systems is believed to be a cationic half-sandwich metal alkyl species, such as $\left[\left(\mathrm{C}_{5} \mathrm{Me}_{4} \mathrm{SiMe}_{3}\right) \mathrm{Sc}-\right.$ $\left.\left(\mathrm{CH}_{2} \mathrm{SiMe}_{3}\right)\right]\left[\mathrm{B}\left(\mathrm{C}_{6} \mathrm{~F}_{5}\right)_{4}\right]$. Compared to scandium complexes, other rare earth metal complexes such as $4(\mathrm{Y}), \mathbf{5}(\mathrm{Gd})$, and 10 (Lu) showed much lower activity (Table 1).

In the present polymerizations, neither atactic nor isotactic polystyrene was observed. Therefore, solvent fractionation was not required to obtain pure sPS ( $r r r r>99 \%$ for all polymers obtained). The molecular weight of the resulting polymers increased almost linearly as the monomer-to-catalyst ratio was increased, while the molecular weight distribution remained narrow $\left(M_{\mathrm{w}} / M_{\mathrm{n}}=1.29-1.55\right)$ (Table 1, entries 1-6), suggesting that this catalyst system has a "living" character. This "living" character became more obvious, when the polymerization was carried out at a lower catalyst concentration, as shown in Figure 2. The "livingness" of the present syndiospecific styrene polymerization catalyst system has been successfully used for the preparation of styrene-ethylene copolymers having syndiotactic styrene-styrene sequences, as described below.

\subsection{Syndiospecific Copolymerization of Styrene with Ethylene}

Syndiotactic polystyrene (sPS) is a very promising polymer material for a large number of applications in industry, because of its high melting point (ca. $270{ }^{\circ} \mathrm{C}$ ), high crystallinity, high modulus of elasticity, low dielectric constant, and excellent resistance to heat and chemicals. ${ }^{6,7}$ A drawback that limits the application scope of sPS, however, is its brittleness. Since the discovery of syndiotactic polystyrene by use of

Table 1. Syndiospecific polymerization of styrene by cationic half-sandwich rare earth metal catalysts $^{\mathrm{a}}$

\begin{tabular}{|c|c|c|c|c|c|c|c|c|c|}
\hline entry & $\begin{array}{c}\text { compd } \\
\text { (Ln) }\end{array}$ & {$[\mathrm{M}] /[\mathrm{Ln}]$} & $\begin{array}{l}\text { time } \\
(\mathrm{min})\end{array}$ & $\begin{array}{c}\text { yield }^{b} \\
(\%)\end{array}$ & activity $^{\mathrm{c}}$ & $\begin{array}{l}\mathrm{sPS}^{\mathrm{d}} \\
(\%)\end{array}$ & $\begin{array}{l}M_{\mathrm{n}}^{\mathrm{e}} \\
\left(10^{4}\right)\end{array}$ & $M_{\mathrm{w}} / M_{\mathrm{n}}{ }^{\mathrm{e}}$ & $\begin{array}{l}T_{\mathrm{m}}^{\mathrm{f}} \\
\left({ }^{\circ} \mathrm{C}\right)\end{array}$ \\
\hline 1 & $1(\mathrm{Sc})$ & 500 & 1 & 100 & $\geq 3125$ & 100 & 8.585 & 1.38 & 271 \\
\hline 2 & $1(\mathrm{Sc})$ & 700 & 1 & 100 & $\geq 4376$ & 100 & 11.96 & 1.29 & 271 \\
\hline 3 & $1(\mathrm{Sc})$ & 1000 & 1 & 100 & $\geq 6034$ & 100 & 13.55 & 1.45 & 272 \\
\hline 4 & $1(\mathrm{Sc})$ & 1500 & 1 & 100 & $\geq 9362$ & 100 & 18.96 & 1.55 & 271 \\
\hline 5 & $\mathbf{1}(\mathrm{Sc})$ & 2000 & 1 & 100 & $\geq 12498$ & 100 & 26.94 & 1.36 & 272 \\
\hline 6 & $\mathbf{1}(\mathrm{Sc})$ & 2500 & 1 & 87 & 13618 & 100 & 37.86 & 1.37 & 273 \\
\hline 7 & $2(\mathrm{Sc})$ & 1000 & 10 & 92 & 146 & 26 & 14.46 & 1.30 & 270 \\
\hline 8 & $3(\mathrm{Sc})$ & 1000 & 1 & 96 & 5892 & 100 & 13.87 & 1.29 & 271 \\
\hline 9 & $4(Y)$ & 100 & 30 & 60 & 13 & 100 & 1.07 & 1.39 & 269 \\
\hline 10 & $5(\mathrm{Gd})$ & 100 & 30 & 69 & 15 & 100 & 0.92 & 1.35 & 269 \\
\hline 11 & $10(\mathrm{Lu})$ & 100 & 30 & 25 & 6 & 100 & 0.49 & 1.38 & 268 \\
\hline
\end{tabular}

${ }^{\mathrm{a}}$ Conditions: $\mathrm{Ln}, 21 \mu \mathrm{mol} ;\left[\mathrm{Ph}_{3} \mathrm{C}\right]\left[\mathrm{B}\left(\mathrm{C}_{6} \mathrm{~F}_{5}\right)_{4}\right], 21 \mu \mathrm{mol}$; solvent/monomer $=5: 1(\mathrm{v} / \mathrm{v}) .{ }^{\mathrm{b}}$ Weight of polymer obtained/weight of monomer used. ${ }^{\mathrm{c}} \mathrm{kg} /(\mathrm{mol}-\mathrm{Ln} \cdot \mathrm{h}) .{ }^{\mathrm{d}}$ Percentage of polymers insoluble in refluxing 2-butanone; $r r r r>99 \%$. ${ }^{e}$ Determined by GPC in $1,2-\mathrm{C}_{6} \mathrm{H}_{4} \mathrm{Cl}_{2}$ at $145{ }^{\circ} \mathrm{C}$ against polystyrene standard. ${ }^{\mathrm{f}}$ Determined by DSC. 


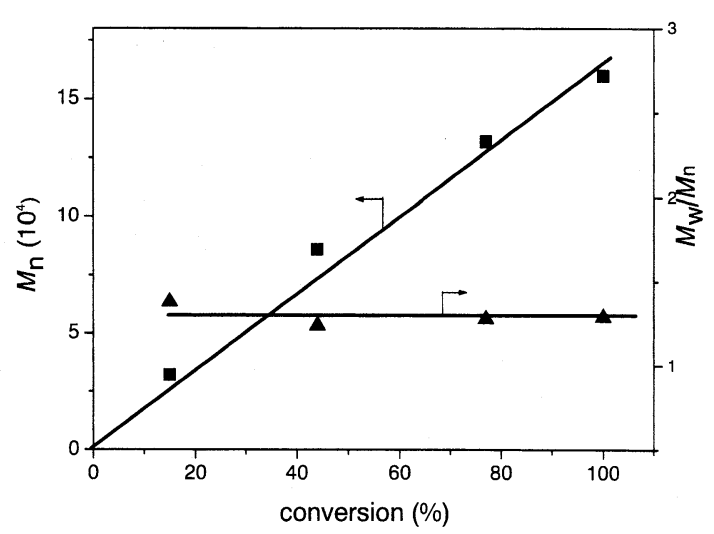

Figure 2. Plots of $M_{\mathrm{n}}$ and $M_{\mathrm{w}} / M_{\mathrm{n}}$ versus styrene conversion. Condition: 1, $21 \mu \mathrm{mol} ;\left[\mathrm{Ph}_{3} \mathrm{C}\right]\left[\mathrm{B}\left(\mathrm{C}_{6} \mathrm{~F}_{5}\right)_{4}\right], 21$ $\mu \mathrm{mol}$; styrene, $21 \mathrm{mmol}$; toluene, $50 \mathrm{~mL} ; 25^{\circ} \mathrm{C}$.

homogeneous titanium catalysts in 1986 by Ishihara et al., ${ }^{6}$ extensive studies on the copolymerization of styrene with ethylene have been carried out to improve the toughness of this new polymer. ${ }^{710-12}$ However, attempts to obtain a styrene-ethylene copolymer having syndiotactic styrenestyrene sequences by use of titanium-based catalyst systems were not successful, because titanium catalysts usually contained a family of different active species, in which the species to produce sPS (probably a Ti(III) species) and that to produce polyethylene (probably a Ti(IV) species) were different from that to yield styrene-ethylene copolymers (unknown species). ${ }^{11}$ In many cases, mixtures of homopolyethylene, homopolystyrene, and varying amounts of styrene-ethylene copolymers with no regio- or stereoregular styrene-styrene sequences were obtained.

In striking contrast, the scandium-based catalyst system such as $1 /\left[\mathrm{Ph}_{3} \mathrm{C}\right]\left[\mathrm{B}\left(\mathrm{C}_{6} \mathrm{~F}_{5}\right)_{4}\right]$ showed excellent activity and selectivity for the syndiospecific copolymerization of styrene with ethylene, because it is a true "single-site" catalyst which contains only the $\mathrm{Sc}(\mathrm{III})$ species. As shown in Table 2, a sequential polymerization of styrene and ethylene by $1 /\left[\mathrm{Ph}_{3} \mathrm{C}\right]\left[\mathrm{B}\left(\mathrm{C}_{6} \mathrm{~F}_{5}\right)_{4}\right]$ afforded straightforwardly the corresponding A-B diblock styrene-ethylene copolymers with a syndiotactic polystyrene block. ${ }^{13}$ The polystyrene content (or the length of the polystyrene block) in the copolymers could be

Table 2. Syndiospecific block-copolymerization of styrene (St) with ethylene (Et) by $1 /\left[\mathrm{Ph}_{3} \mathrm{C}\right]\left[\mathrm{B}\left(\mathrm{C}_{6} \mathrm{~F}_{5}\right)_{4}\right]^{a}$

\begin{tabular}{|c|c|c|c|c|c|c|c|c|}
\hline$h^{\prime}$ & \multicolumn{4}{|c|}{ toluene, $25^{\circ} \mathrm{C},{ }^{-100 \%}$ conv. } & \multicolumn{4}{|c|}{$1 \mathrm{~atm}, 2 \mathrm{~min}, 25^{\circ} \mathrm{C} \quad \mathrm{Ph} \quad \mathrm{Ph}$} \\
\hline \multirow[b]{2}{*}{ run } & St & yield & & PS cont ${ }^{c}$ & $M_{\mathrm{n}}{ }^{d}$ & & $T_{\mathrm{g}}^{e}$ & $T_{\mathrm{m}}^{e}$ \\
\hline & $(\mathrm{mmol})$ & (g) & activity $^{b}$ & $(\mathrm{~mol} \%)$ & $\times 10^{-4}$ & $M_{\mathrm{w}} / M_{\mathrm{n}}{ }^{d}$ & $\left({ }^{\circ} \mathrm{C}\right)$ & $\left({ }^{\circ} \mathrm{C}\right)$ \\
\hline 1 & 10 & 1.33 & 224 & 50 & 10.35 & 1.83 & n.o..$^{f}$ & 116,272 \\
\hline 2 & 21 & 2.35 & 395 & 71 & 18.43 & 2.22 & 97 & 267 \\
\hline 3 & 31 & 3.48 & 585 & 83 & 20.91 & 1.92 & 98 & 273 \\
\hline
\end{tabular}

${ }^{a}$ Polymerization conditions: toluene, $50 \mathrm{~mL}$; Sc, $21 \mu \mathrm{mol} ;\left[\mathrm{Ph}_{3} \mathrm{C}\right]\left[\mathrm{B}\left(\mathrm{C}_{6} \mathrm{~F}_{5}\right)_{4}\right], 21 \mu \mathrm{mol}$; ethylene, 1 atm. ${ }^{b} \mathrm{Kg}$ of copolymer/(mol-Sc atm $\left.\cdot h\right) .{ }^{c}$ Calculated from ${ }^{1} \mathrm{H}$ NMR spectra measured in $1,1,2,2$-tetrachloroethane- $d_{2}$ at $120{ }^{\circ} \mathrm{C}$. ${ }^{d}$ Determined by GPC in 1,2dichlorobenzene at $145{ }^{\circ} \mathrm{C}$ against polystyrene standard. ${ }^{e}$ Measured by DSC. ${ }^{f}$ Not observed. easily controlled by changing the styrene feed.

When the copolymerization reactions were carried out in the presence of both ethylene and styrene, multi-block styrene-ethylene copolymers which consist of syndiotactic styrene-styrene sequences (blocks) connected by repeated ethylene units were obtained (Table 3 ). ${ }^{4 a}$ The styrene content in the copolymers could be controlled simply by changing the initial styrene feed under 1 atm of ethylene. Solvent fractionation experiments confirmed that the copolymer products did not contain homopolymers. ${ }^{13} \mathrm{C}$ NMR analyses did not show any tail-to-tail or head-to-head styrene sequences in the copolymers. The GPC curves of the copolymers were all unimodal with very narrow molecular weight distributions $\left(M_{\mathrm{w}} / M_{\mathrm{n}}=1.14-1.26\right)$, indicative of single homogeneous catalyst behavior. This is the first example of syndiospecific copolymerization of styrene with ethylene.

\subsection{Polymerization of 1-Hexene}

The combination of the half-sandwich scandium bis(alkyl) complexes 1-3 with 1 equiv of $\left[\mathrm{Ph}_{3} \mathrm{C}\right]\left[\mathrm{B}\left(\mathrm{C}_{6} \mathrm{~F}_{5}\right)_{4}\right]$ also showed high activity for the polymerization of 1-hexene, with an activity order of $\mathbf{1}>\mathbf{3}>\mathbf{2}$ (Table 4$).{ }^{14}$ The average number molecular weight $\left(M_{\mathrm{n}}\right)$ of the polymers obtained at room temperature was rather low $\left(M_{\mathrm{n}}=4800-5800\right)$, and was independent of the amount of monomer consumed (Table 4, entries 1, 2, 6 and 7). However, when the polymerization was carried out at low temperatures (Table 4, entries 3-5), the molecular weight of the resulting polymers increased dramatically, and reached as high as $332.5 \times 10^{3}$ at $-40{ }^{\circ} \mathrm{C}$. These results suggest that a chain transfer reaction must occur rapidly at room temperature but could be suppressed efficiently at lower temperatures. The ${ }^{1} \mathrm{H}$ NMR analysis of the polymer product (oligomer) obtained at room temperature revealed that the present polymerization reactions proceeded in both $1,2-$ and 2,1-insertion fashions, with $\beta$-hydrogen elimination as a chain termination reaction. Under the same conditions, complexes 4-10 did not show activity for 1-hexene polymerization, demonstrating again the metal dependence of the catalyst activity.

Very recently, dicationic scandium alkyl complexes bearing non- $\mathrm{Cp}$ ligands were also reported to show high activity for 1-hexene polymerization. ${ }^{15}$ Neutral rare earth metal complexes usually show no or very low activity for the polymerization of $\alpha$-olefins. ${ }^{16}$

\subsection{Copolymerization of 1-Hexene with Ethylene}

The $1 /\left[\mathrm{Ph}_{3} \mathrm{C}\right]\left[\mathrm{B}\left(\mathrm{C}_{6} \mathrm{~F}_{5}\right)_{4}\right]$ catalyst system also showed high activity for the copolymerization of 1-hexene with ethylene to produce ethylene/1-hexene copolymers containing isolated butyl branches in the chain backbone (Table 5). ${ }^{14}$ When 1-hexene feed was raised under $1 \mathrm{~atm}$ of ethylene, the incorporation of 1-hexene increased significantly (Table 5 , entries $3-5$ ). It is also noteworthy that the polymerization activity of the present catalyst was also increased significantly with the increase of 1-hexene feed, which thus constitutes a rare example of a homogeneous polymerization catalyst that shows significant positive "comonomer effect" in the copolymerization of ethylene with an $\alpha$-olefin. ${ }^{17}$ The activity of the present catalyst system for the copolymerization of 1-hexene with 
Table 3. "Multi-block" syndiospecific copolymerization of styrene (St) with ethylene (Et) by $\mathbf{1} /\left[\mathrm{Ph}_{3} \mathrm{C}\right]\left[\mathrm{B}\left(\mathrm{C}_{6} \mathrm{~F}_{5}\right)_{4}\right]^{\mathrm{a}}$

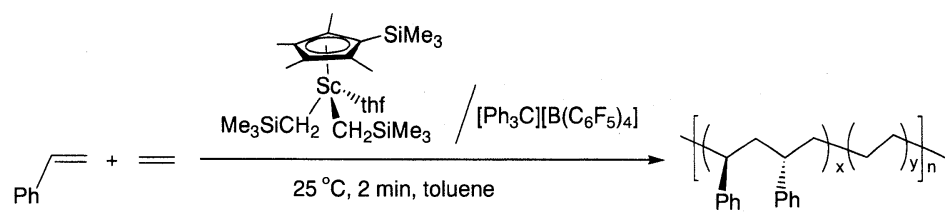

\begin{tabular}{ccccccccc}
\hline entry & $\begin{array}{c}\text { St } \\
(\mathrm{mmol})\end{array}$ & $\begin{array}{c}\text { Et } \\
(\mathrm{atm})\end{array}$ & $\begin{array}{c}\text { yield } \\
(\mathrm{g})\end{array}$ & activity $^{\mathrm{b}}$ & $\begin{array}{c}\mathrm{St} \mathrm{cont}^{\mathrm{c}} \\
(\mathrm{mol} \%)\end{array}$ & $\begin{array}{c}M_{\mathrm{n}}{ }^{\mathrm{d}} \\
\left(10^{4}\right)\end{array}$ & $M_{\mathrm{w}} / M_{\mathrm{n}}{ }^{\mathrm{d}}$ & $\begin{array}{c}T_{\mathrm{m}}{ }^{\mathrm{e}} \\
\left({ }^{\circ} \mathrm{C}\right)\end{array}$ \\
\hline 1 & 0 & 1 & 0.55 & 786 & 0 & 17.23 & 1.72 & 127 \\
2 & 21 & 0 & 0.45 & 643 & 100 & 6.04 & 1.41 & 268 \\
3 & 10 & 1 & 0.40 & 600 & 13 & 7.92 & 1.14 & n.o. \\
4 & 21 & 1 & 0.79 & 1123 & 56 & 11.13 & 1.19 & 214 \\
5 & 31 & 1 & 0.92 & 1314 & 65 & 16.26 & 1.17 & 233 \\
6 & 41 & 1 & 1.62 & 2314 & 87 & 15.09 & 1.26 & 245
\end{tabular}

${ }^{a}$ Conditions: Sc, $21 \mu \mathrm{mol} ;\left[\mathrm{Ph}_{3} \mathrm{C}\right]\left[\mathrm{B}\left(\mathrm{C}_{6} \mathrm{~F}_{5}\right)_{4}\right], 21 \mu \mathrm{mol}$; toluene, $50 \mathrm{~mL} .{ }^{\mathrm{b}} \mathrm{kg} /(\mathrm{mol}-\mathrm{Sc} \cdot \mathrm{atm} \cdot \mathrm{h}) .{ }^{\mathrm{c}}$ Determined by ${ }^{1} \mathrm{H}$ NMR. ${ }^{d}$ Determined by GPC in $1,2-\mathrm{C}_{6} \mathrm{H}_{4} \mathrm{Cl}_{2}$ at $145^{\circ} \mathrm{C}$ against polystyrene standard. ${ }^{\mathrm{e}}$ Determined by DSC. ${ }^{\mathrm{f}}$ Not observed.

Table 4. Homopolymerization of 1-hexene by cationic half-sandwich scandium catalysts ${ }^{\mathrm{a}}$

\begin{tabular}{|c|c|c|c|c|c|c|c|c|}
\hline entry & compd & {$[\mathrm{M}] /[\mathrm{Sc}]$} & $\begin{array}{c}\mathrm{T} \\
\left({ }^{\circ} \mathrm{C}\right)\end{array}$ & $\begin{array}{l}\text { time } \\
(\min )\end{array}$ & $\begin{array}{c}\text { conv } \\
(\%)\end{array}$ & Activity $^{\mathrm{b}}$ & $\begin{array}{c}M_{\mathrm{n}}^{\mathrm{c}} \\
\left(10^{3}\right)\end{array}$ & $M_{\mathrm{w}} / M_{\mathrm{n}}{ }^{\mathrm{c}}$ \\
\hline 1 & 1 & 1000 & 25 & 15 & 97 & 322 & 5.8 & 1.65 \\
\hline 2 & 1 & 1500 & 25 & 30 & 90 & 446 & 5.7 & 1.67 \\
\hline 3 & 1 & 1000 & 0 & 30 & 85 & 140 & 27.7 & 1.58 \\
\hline 4 & 1 & 1000 & -15 & 60 & 87 & 71 & 144.1 & 1.43 \\
\hline 5 & 1 & 1000 & -40 & 150 & 78 & 26 & 332.5 & 1.48 \\
\hline 6 & 2 & 1000 & 25 & 15 & 26 & 86 & 4.8 & 1.51 \\
\hline 7 & 3 & 1000 & 25 & 15 & 64 & 213 & 5.6 & 1.58 \\
\hline
\end{tabular}

${ }^{\mathrm{a}}$ Conditions: $\mathrm{Sc}, 21 \mu \mathrm{mol} ;\left[\mathrm{Ph}_{3} \mathrm{C}\right]\left[\mathrm{B}\left(\mathrm{C}_{6} \mathrm{~F}_{5}\right)_{4}\right], 21 \mu \mathrm{mol}$; toluene/monomer, $5: 1(\mathrm{v} / \mathrm{v}) .{ }^{\mathrm{b}} \mathrm{kg} /(\mathrm{mol}-\mathrm{Sc} \cdot \mathrm{h}){ }^{\mathrm{c}}$ Determined by GPC in THF at $40^{\circ} \mathrm{C}$ against polystyrene standard.

ethylene could reach as high as ca. $2.3 \times 10^{3} \mathrm{~kg} /(\mathrm{mol}-\mathrm{Sc}$. atm $\cdot h$ ) at room temperature (Table 4 , entry 5), which ranks the highest ever reported for a rare earth metal catalyst for ethylene-1-hexene copolymerization, ${ }^{16}$ and could be compared with those reported for the most active group 4 metal catalysts. ${ }^{17}$

In the case of $3\left(\mathrm{Cp}^{\prime}=\mathrm{C}_{5} \mathrm{Me}_{5}\right)$ (Table 5, entry 6), the incorporation of 1 -hexene was much lower $(2 \mathrm{~mol} \%)$ under the same conditions, while in the case of $\mathbf{2}\left(\mathrm{Cp}^{\prime}=\right.$ $\left.\mathrm{C}_{5} \mathrm{H}_{3}\left(\mathrm{SiMe}_{3}\right)_{2}-1,3\right)$, no incorporation of 1 -hexene was observed. These results are consistent with the activity of these catalysts for 1-hexene homopolymerization.

\section{Polymerization and Copolymerization of Cyclic Olefins}

Cyclic olefin copolymers (COCs) have recently attracted significant interest as one of the most important engineering plastics for thermally stressed and optical applications because of their many desirable properties such as thermal stability, good transparency, and chemical resistance. Since Kaminsky first described the copolymerization of ethylene with norbornene using zirconocene-based catalysts in $19911^{18}$ extensive studies have been carried out in this area. ${ }^{19}$ Most of the catalysts reported so far in the literature are based on $\mathrm{d}$-transition metals such as group 4 and group 10 metals, ${ }^{19}$ whereas the use of a rare earth metal complex for the copolymerization of cyclic olefins remained almost unexplored. It was recently found that the cationic half-sandwich scandium alkyl species generated in-situ by reaction of a bis(alkyl) complex such 1 or 3 with $\left[\mathrm{Ph}_{3} \mathrm{C}\right]\left[\mathrm{B}\left(\mathrm{C}_{6} \mathrm{~F}_{5}\right)_{4}\right]$ can act as an excellent catalyst system for the copolymerization of ethylene with cyclic olefins, which constitutes the first example of a rare earth metal catalyst for the copolymerization of cyclic olefins. ${ }^{5 b, 20}$ 
Table 5. Copolymerization of 1-hexene (Hex) with ethylene (Et) by cationic half-sandwich scandium catalysts ${ }^{\mathrm{a}}$

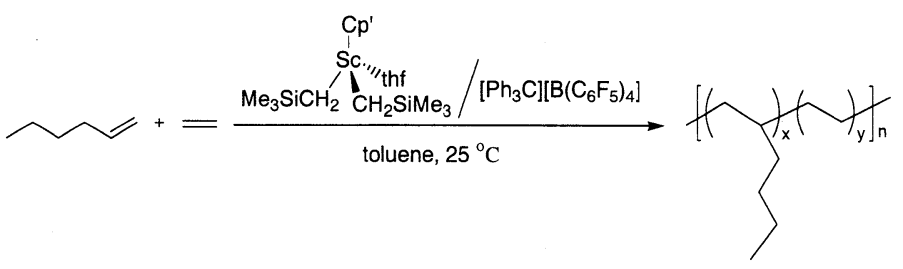

\begin{tabular}{cccccccccc}
\hline entry compd & $\begin{array}{c}\mathrm{Hex} \\
(\mathrm{mmol})\end{array}$ & $\begin{array}{c}\mathrm{Et} \\
(\mathrm{atm})\end{array}$ & $\begin{array}{c}\text { time } \\
(\mathrm{min})\end{array}$ & $\begin{array}{c}\text { yield } \\
(\mathrm{g})\end{array}$ & activity $^{\mathrm{b}}$ & $\begin{array}{c}\mathrm{Hex} \mathrm{cont}^{\mathrm{c}} \\
(\mathrm{mol} \%)\end{array}$ & $\begin{array}{c}M_{\mathrm{n}}{ }^{\mathrm{d}} \\
\left(10^{3}\right)\end{array}$ & $M_{\mathrm{w}} / M_{\mathrm{n}}{ }^{\mathrm{d}}$ \\
\hline 1 & $\mathbf{1}$ & 0 & 1 & 5 & 1.13 & 658 & 0 & 213.5 & 1.75 \\
2 & $\mathbf{1}$ & 21 & 0 & 15 & 1.33 & 258 & 100 & 4.9 & 1.49 \\
3 & $\mathbf{1}$ & 21 & 1 & 5 & 2.26 & 1291 & 13 & 1.97 & 3.14 \\
4 & $\mathbf{1}$ & 42 & 1 & 5 & 3.38 & 1932 & 23 & 1.37 & 2.74 \\
5 & $\mathbf{1}$ & 84 & 1 & 5 & 3.98 & 2274 & 32 & 1.09 & 2.16 \\
6 & $\mathbf{3}$ & 21 & 1 & 5 & 0.99 & 565 & 2 & 206.2 & 2.59 \\
\hline
\end{tabular}

Determined by ${ }^{1} \mathrm{H}$ NMR. ${ }^{d}$ Determined by GPC in $1,2-\mathrm{C}_{6} \mathrm{H}_{4} \mathrm{Cl}_{2}$ at $145^{\circ} \mathrm{C}$ against polystyrene standard.

\subsection{Alternating Copolymerization of Norbornene with Ethylene}

On treatment with 1 equiv of $\left[\mathrm{Ph}_{3} \mathrm{C}\right]\left[\mathrm{B}\left(\mathrm{C}_{6} \mathrm{~F}_{5}\right)_{4}\right]$, complexes 1-3 all showed very high activity for the alternating copolymerization of norbornene with ethylene, with an activity order of $\mathbf{1}>\mathbf{2}>\mathbf{3}$ (Table 6 , entries $3-5$ ). ${ }^{4 \mathrm{~b}}$ A strong depen- dence of the copolymerization activity on the monomer concentration (or the ethylene/norbornene molar ratio in the reaction solution) was observed (Table 6, entries 3, 9-13). Under appropriate (ethylene/norbornene molar ratio) conditions, the catalytic activity could reach as high as $25.2 \times 10^{3}$ $\mathrm{kg} /(\mathrm{mol}-\mathrm{Sc} \cdot \mathrm{h} \cdot \mathrm{atm})($ Table 6 , entry 9$)$, which as far as we are

Table 6. Alternating copolymerization of norbornene (NB) with ethylene (Et) by cationic half-sandwich scandium catalysts ${ }^{\mathrm{a}}$

\begin{tabular}{|c|c|c|c|c|c|c|c|c|c|c|c|}
\hline entry & compd & $\begin{array}{c}\text { Et } \\
\text { (atm) }\end{array}$ & $\begin{array}{c}\mathrm{NB} \\
(\mathrm{mmol})\end{array}$ & $\begin{array}{c}\mathrm{T} \\
\left({ }^{\circ} \mathrm{C}\right)\end{array}$ & $\begin{array}{c}\mathrm{V} \\
(\mathrm{mL})\end{array}$ & $\begin{array}{c}\text { yield } \\
\text { (g) }\end{array}$ & activity $^{\mathrm{D}}$ & $\begin{array}{r}\mathrm{NB} \mathrm{cont}^{\mathrm{c}} \\
(\mathrm{mol} \%)\end{array}$ & $\begin{array}{c}M_{n}{ }^{d} \\
\left(10^{4}\right)\end{array}$ & $\mathrm{PDI}^{\mathrm{d}}$ & $\begin{array}{c}T_{\mathrm{E}}^{\mathrm{e}} \\
\left({ }^{\circ} \mathrm{C}\right)\end{array}$ \\
\hline 1 & 1 & 1 & 0 & 25 & 40 & 0.03 & 0.4 & - & n.d. ${ }^{f}$ & n.d. & n.d. \\
\hline $2^{g}$ & 1 & 0 & 20 & 25 & 10 & 0.02 & 0.0005 & 100 & n.d. & n.d. & n.d. \\
\hline 3 & 1 & 1 & 20 & 25 & 40 & 0.67 & 8.0 & 41.2 & 11.0 & 1.79 & 126 \\
\hline 4 & 2 & 1 & 20 & 25 & 40 & 0.47 & 5.6 & 36.1 & 4.9 & 1.89 & 105 \\
\hline 5 & 3 & 1 & 20 & 25 & 40 & 0.20 & 2.4 & 42.9 & 5.8 & 2.22 & 101 \\
\hline 6 & 1 & 1 & 20 & 0 & 40 & 0.35 & 4.2 & 35.7 & 12.1 & 1.49 & 104 \\
\hline 7 & 1 & 1 & 20 & 50 & 40 & 0.81 & 9.7 & 42.5 & 8.0 & 1.81 & 119 \\
\hline 8 & 1 & 1 & 20 & 70 & 40 & 0.97 & 11.6 & 43.2 & 4.0 & 2.33 & 127 \\
\hline 9 & 1 & 1 & 30 & 25 & 40 & 2.10 & 25.2 & 44.2 & 8.5 & 2.19 & 118 \\
\hline 10 & 1 & 1 & 40 & 25 & 40 & 0.31 & 3.7 & 45.5 & 7.4 & 1.80 & 120 \\
\hline 11 & 1 & 1 & 20 & 25 & 60 & 0.62 & 7.4 & 35.8 & 15.4 & 1.65 & 105 \\
\hline 12 & 1 & 1 & 20 & 25 & 20 & 1.29 & 15.5 & 46.4 & 6.5 & 1.92 & 134 \\
\hline 13 & 1 & 1 & 20 & 25 & 10 & 0.37 & 4.4 & 48.1 & 3.2 & 2.08 & 128 \\
\hline
\end{tabular}

${ }^{\text {a }}$ Conditions: $\mathrm{Sc}, 1 \mu \mathrm{mol} ;\left[\mathrm{Ph}_{3} \mathrm{C}\right]\left[\mathrm{B}\left(\mathrm{C}_{6} \mathrm{~F}_{5}\right)_{4}\right], 1 \mu \mathrm{mol}$; toluene, $40 \mathrm{~mL} ; 25^{\circ} \mathrm{C}, 5 \mathrm{~min}$, unless otherwise noted. ${ }^{\mathrm{b}} 10^{3} \mathrm{~kg} /($ mol-Sch $\mathrm{h} \cdot \mathrm{atm}) .{ }^{\mathrm{c}}$ Determined by ${ }^{13} \mathrm{C}$ NMR. ${ }^{d}$ Determined by GPC in $1,2-\mathrm{C}_{6} \mathrm{H}_{4} \mathrm{Cl}_{2}$ at $145{ }^{\circ} \mathrm{C}$ using polystyrene standard. ${ }^{\mathrm{e}}$ Measured by DSC. ${ }^{\mathrm{f}}$ Not determined. ${ }^{\mathrm{g}}$ Conditions: Sc, $21 \mu \mathrm{mol}$; $\left[\mathrm{Ph}_{3} \mathrm{C}\right]\left[\mathrm{B}\left(\mathrm{C}_{6} \mathrm{~F}_{5}\right)_{4}\right], 21 \mu \mathrm{mol} ; 2 \mathrm{~h}$. 
aware, is the highest ever reported for the copolymerization of ethylene and norbornene.

Possibly due to steric hindrance, successive norbornene insertion or homopolymerization of norbornene is sluggish in the present catalyst system. However, the insertion of a norbornene monomer into a $\mathrm{Sc}-\mathrm{CH}_{2} \mathrm{CH}_{2} \mathrm{R}$ bond and that of an ethylene monomer into a Sc-norbornyl bond could be very fast, and the former could be even more preferred to successive ethylene insertion when an adequate amount of norbornene is present. This unique nature led to rapid and exclusive formation of the alternating ethylene-norbornene copolymer under appropriate ethylene/norbornene molar ratios. When a relatively small amount of norbornene was used under $1 \mathrm{~atm}$ of ethylene, poly(ethylene-alt-norbornene)$b$-polyethylene block copolymers could be obtained (Scheme 3). Analogously, poly(ethylene-alt-norbornene)-bpolystyrene block copolymers and poly(ethylene-alt-norbornene) $-b$-polyethylene- $b$-polystyrene triblock copolymers could also be obtained by use of the procedures shown in Scheme $3 .^{4 \mathrm{~b}, 21}$

\subsection{Random Terpolymerization of Norbornene, Ethylene, and Styrene}

Although the incorporation of an aromatic monomer such as styrene into COCs is of much interest, random terpolymerization of ethylene, styrene, and a cyclic olefin was hardly explored. ${ }^{22}$ Since the cationic half-sandwich scandium catalysts showed unique activity for both the copolymerization of ethylene with styrene and the copolymerization of ethylene with norbornene, the activity of this new catalyst system for the terpolymerization of ethylene, norbornene, and styrene was further examined. ${ }^{20,21}$

The $1 /\left[\mathrm{Ph}_{3} \mathrm{C}\right]\left[\mathrm{B}\left(\mathrm{C}_{6} \mathrm{~F}_{5}\right)_{4}\right]$ combination did not copolymerize styrene and norbornene, which yielded only homopolystyrene in the presence of both monomers (Table 7, entry 4). In contrast, the random terpolymerization of ethylene, styrene, and norbornene took place rapidly under the coexistence of the three monomers. By changing the norbornene/styrene feed ratios under $1 \mathrm{~atm}$ of ethylene, the corresponding terpolymers with styrene contents of $7-53 \mathrm{~mol} \%$ and norbornene contents of 7-27 mol\% could be easily prepared (Table 7, entries 5 , 8-15). Complexes $2\left(\mathrm{Cp}^{\prime}=\mathrm{C}_{5} \mathrm{H}_{3}\left(\mathrm{SiMe}_{3}\right)_{2}-1,3\right)$ and $3\left(\mathrm{Cp}^{\prime}=\right.$ $\mathrm{C}_{5} \mathrm{Me}_{5}$ ) were also active for this terpolymerization reaction, although their activity and incorporation of styrene or norbornene were lower than those of $\mathbf{1}$ under the same condi-

Scheme 3. Synthesis of various block copolymers containing ethylene, norbornene, and styrene units

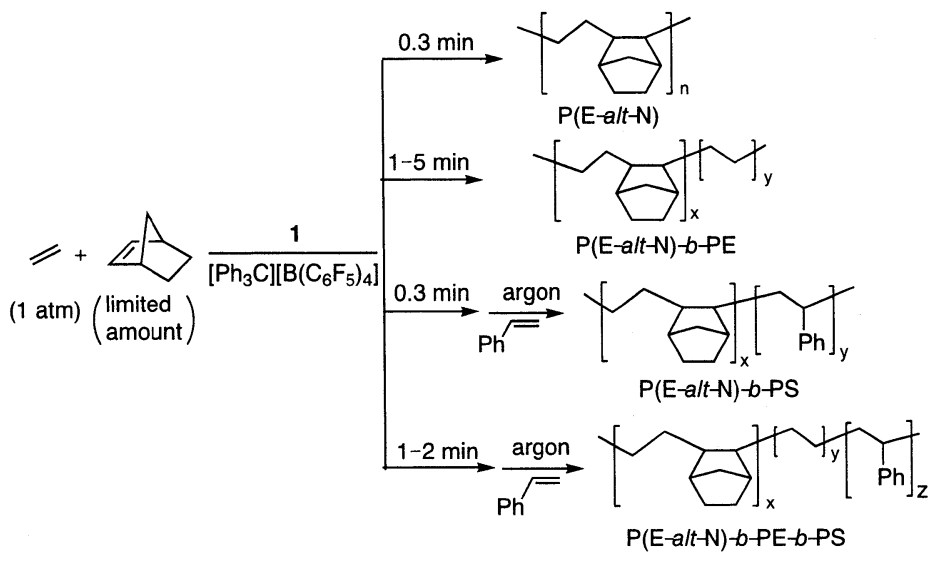

tions (Table 7, entries 5-7).

${ }^{13} \mathrm{C}$ NMR analyses showed the terpolymer products are random terpolymers containing isolated or alternating NB units, isolated styrene units and syndiotactic styrene-styrene sequences. No styrene-NB sequences were found in the terpolymer backbone. These results are consistent with what was observed for the two-component copolymerization reactions. The high and controllable incorporation of styrene in the present terpolymerizations is particularly noteworthy, and is in striking contrast with what was observed for the only previously reported titanium catalyst for the terpolymerization of ethylene, styrene, and norbornene, in which the maximum incorporation of styrene was less than $3 \mathrm{~mol} \%{ }^{22}$ This is the first example of efficient terpolymerization of ethylene, styrene, and a cyclic olefin.

\subsection{Alternating Copolymerization of Dicyclopentadiene (DCPD) with Ethylene}

Cyclic olefin copolymers (COCs) have so far been dominated by those of strained cyclic olefins such as norbornene and cyclopentene. ${ }^{18,19}$ In comparison with norbornene and cyclopentene, dicyclopentadiene (DCPD) is a very promising and attractive cyclic olefin monomer, because it contains both a norbornene unit and a cyclopentene unit, and is industrially available at a much lower price. Moreover, if only one of the two C-C double bonds in DCPD selectively participates in the copolymerization with another monomer such as ethylene, further functionalization of the remaining $\mathrm{C}-\mathrm{C}$ double bonds in the resulting copolymers is possible to introduce polar groups into the polymer backbone, giving a broad range of new functionalized polymers with improved properties. Nevertheless, the copolymerization of ethylene with DCPD has been far less extensively studied, and the alternating copolymerization of ethylene with DCPD has not been reported previously in the literature. ${ }^{23}$ Cross-linking appeared to be a major problem often encountered in DCPD copolymerization, ${ }^{23 \mathrm{c}}$ and, therefore, the search for a catalyst system that is not only sufficiently active but can also distinguish a norbornene unit from a cyclopentene unit is critically important to achieve ethylene-DCPD copolymerization in a controlled fashion. A cationic half-sandwich scandium alkyl system, such as $1 /\left[\mathrm{Ph}_{3} \mathrm{C}\right]\left[\mathrm{B}\left(\mathrm{C}_{6} \mathrm{~F}_{5}\right)_{4}\right]$, proved to be such an excellent catalyst for the copolymerization of DCPD with ethylene. ${ }^{20}$

In the presence of $1 /\left[\mathrm{Ph}_{3} \mathrm{C}\right]\left[\mathrm{B}\left(\mathrm{C}_{6} \mathrm{~F}_{5}\right)_{4}\right]$ in toluene, the copolymerization of DCPD with ethylene took place very rapidly at a wide range of temperatures $\left(0-70{ }^{\circ} \mathrm{C}\right)$ to yield the corresponding alternating copolymers, although DCPD homopolymerization was very slow under similar conditions (Table 8) ${ }^{20}$ The DCPD content of the resulting copolymers increased as the DCPD monomer feed was raised under 1 atm of ethylene, and reached as high as $45 \mathrm{~mol} \%$ when 50 mmol of DCPD was used (Table 8, entries 3-8). The catalytic activity also increased as the DCPD monomer feed was increased in the range of 20-40 $\mathrm{mmol}$ (Table 8, entries 3-7), while the use of more DCPD (50 mmol) led to decrease in activity (Table 8 , entry 8 ). These results suggest that the ethylene-DCPD alternating copolymerization is more preferred than the homopolymerization of either monomer, similar to what was observed in the scandium-catalyzed ethylene-norbornene copolymerization. $^{4 \mathrm{~b}}$

${ }^{1} \mathrm{H}$ and ${ }^{13} \mathrm{C}$ NMR analyses revealed that the resulting 
Table 7. Random terpolymerization of norbornene (NB), ethylene (Et), and styrene (St) by cationic half-sandwich scandium catalysts ${ }^{a}$

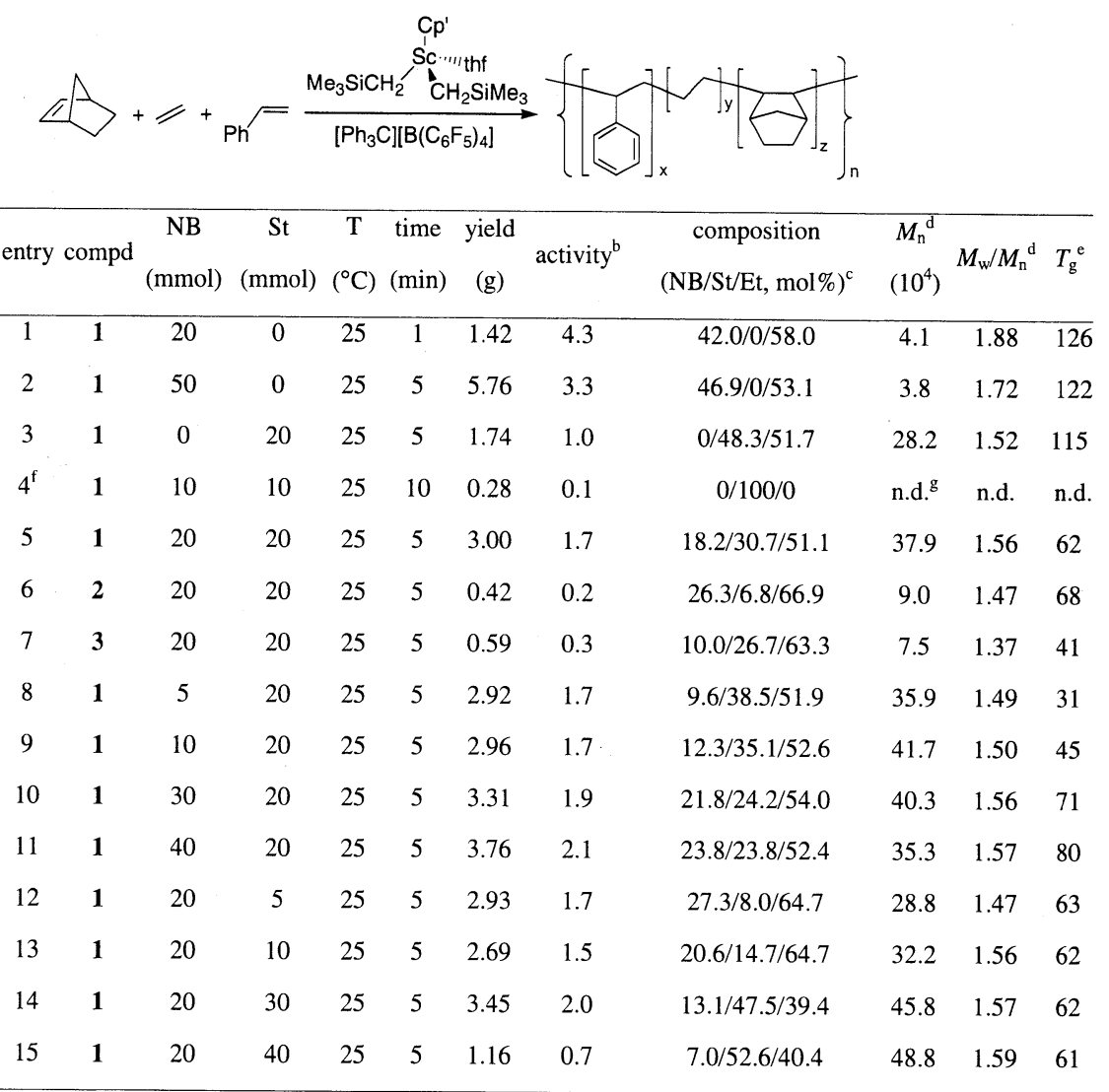

${ }^{\mathrm{a}}$ Conditions: compd $21 \mu \mathrm{mol} ;\left[\mathrm{Ph}_{3} \mathrm{C}\right]\left[\mathrm{B}\left(\mathrm{C}_{6} \mathrm{~F}_{5}\right)_{4}\right], 21 \mu \mathrm{mol} ; P_{\text {ethylene }}=1$ atm; toluene $40 \mathrm{~mL}$ unless otherwise noted. ${ }^{b} 10^{3} \mathrm{~kg} /(\mathrm{mol}-\mathrm{Sc} \cdot \mathrm{h} \cdot \mathrm{atm}) .{ }^{\mathrm{c}}$ Determined by ${ }^{1} \mathrm{H}$ NMR. ${ }^{\mathrm{d}}$ Determined by GPC in $1,2-$ $\mathrm{C}_{6} \mathrm{H}_{4} \mathrm{Cl}_{2}$ at $145^{\circ} \mathrm{C}$ against polystyrene standard. ${ }^{\mathrm{e}}$ Measured by DSC. ${ }^{\mathrm{f}} P_{\text {ethylene }}=0 \mathrm{~atm}$; toluene, $20 \mathrm{~mL}$. ${ }^{\mathrm{g}}$ Not determined.

ethylene-DCPD copolymers contained cyclopetene units, suggesting that the copolymerization proceeded through enchainment of the norbornene ring. Their GPC curves are all unimodal with relatively narrow molecular weight distributions (1.73-2.69), consistent with the predominance of a single homogeneous catalytic species and the good selectivity in the copolymerization.

Epoxidation of an ethylene-DCPD alternating copolymer could be easily achieved by use of $m$-chloroperbenzoic acid ( $m$ CPBA) as an oxidant, which quantitatively converted the olefinic groups into epoxy groups (Scheme 4).

Scheme 4. Epoxidation of an alternating ethylene-DCPD copolymer

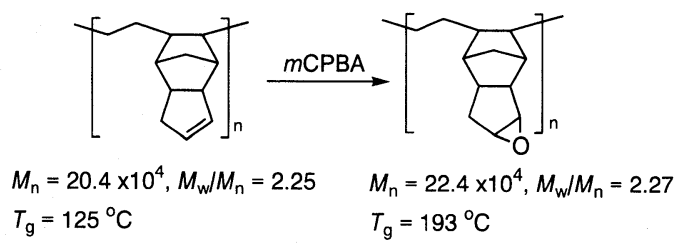

\subsection{Terpolymerization of Dicyclopentadiene, Ethylene, and Styrene}

Similar to that of norbornene, ethylene, and styrene, the terpolymerization of DCPD, ethylene, and styrene could also be achieved by use of $1 /\left[\mathrm{Ph}_{3} \mathrm{C}\right]\left[\mathrm{B}\left(\mathrm{C}_{6} \mathrm{~F}_{5}\right)_{4}\right]$ as a catalyst (Table 9). ${ }^{20}$ The terpolymers with styrene contents of $4-57 \mathrm{~mol} \%$ and DCPD contents of 5-26 mol \% could be easily prepared by changing the DCPD/styrene feed ratio under $1 \mathrm{~atm}$ of ethylene, ${ }^{13} \mathrm{C}$ NMR analyses revealed that the terpolymers are random copolymers that contain isolated or alternating DCPD units, isolated styrene units, and syndiotactic styrene-styrene sequences, while no styrene-DCPD sequences wcrc obscrved. These results are in agreement with those observed for the ethylene-DCPD, ${ }^{20}$ styrene-DCPD, and ethylene-styrene ${ }^{4 a}$ two-component copolymerizations, and are similar to those of the terpolymerization of norbornene, ethylene, and styrene.

\subsection{Syndiospecific 1,4-Polymerization of \\ 1,3-Cyclohexadiene (CHD)}

Cyclohexadiene (CHD) is a promising cyclic olefin monomer for the preparation of COCs containing six-membered rings in the backbone. Homopolymerization of CHD could be achieved by various initiators/catalysts such as free radicals, ${ }^{24}$ anionic ${ }^{25}$ or cationic initiators, ${ }^{26}$ and Ziegler-Natta catalysts. ${ }^{27}$ However, control of the regio- and stereoselectivity of the CHD polymerization by these conventional catalysts was difficult. Recently, homogeneous nickel catalysts were reported to show regio- and stereoselectivity for the polymerization of CHD. ${ }^{28}$ Unfortunately, however, the poly(CHD)s obtained were insoluble and showed melting temperatures of higher than $300{ }^{\circ} \mathrm{C}$, and therefore, these polymers were not melt-processable and were difficult to be characterized by conventional spectroscopic techniques. More recently, titanium constrained geometry catalysts were reported to give soluble poly(CHD)s, but the maximum 1,4-regioselectivity 
Table 8. Alternating copolymerization of dicyclopentadiene (DCPD) with ethylene by $1 /\left[\mathrm{Ph}_{3} \mathrm{C}\right]\left[\mathrm{B}\left(\mathrm{C}_{6} \mathrm{~F}_{5}\right)_{4}\right]^{\mathrm{a}}$

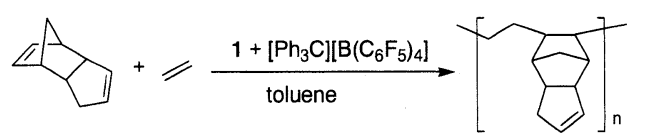

\begin{tabular}{|c|c|c|c|c|c|c|c|c|c|c|}
\hline entry & $\begin{array}{r}\text { DCPD } \\
(\mathrm{mmol})\end{array}$ & $\begin{array}{c}\mathrm{T} \\
\left({ }^{\circ} \mathrm{C}\right)\end{array}$ & $\begin{array}{c}\mathrm{V} \\
(\mathrm{mL})\end{array}$ & $\begin{array}{l}\text { yield } \\
\text { (g) }\end{array}$ & activity $^{b}$ & $\begin{array}{c}\text { DCPD conv } \\
(\%)\end{array}$ & $\begin{array}{c}\text { DCPD cont }^{\mathrm{c}} \\
(\mathrm{mol} \%)\end{array}$ & $\begin{array}{l}M_{\mathrm{n}}{ }^{\mathrm{d}} \\
\left(10^{4}\right)\end{array}$ & $M_{\mathrm{w}} / M_{\mathrm{n}}^{\mathrm{d}}$ & $\begin{array}{l}T_{\mathrm{g}}{ }^{\mathrm{e}} \\
\left({ }^{\circ} \mathrm{C}\right)\end{array}$ \\
\hline 1 & 0 & 25 & 40 & 1.48 & 0.8 & - & - & 13.1 & 2.55 & n.d. ${ }^{f}$ \\
\hline $2^{\mathrm{g}}$ & 40 & 25 & 5 & 0.08 & - & 2 & 100 & n.d. & n.d. & n.d. \\
\hline 3 & 20 & 25 & 40 & 3.67 & 2.1 & 100 & 35.1 & 19.9 & 1.73 & 101 \\
\hline 4 & 25 & 25 & 40 & 4.50 & 2.6 & 100 & 38.5 & 22.6 & 2.69 & 115 \\
\hline 5 & 30 & 25 & 40 & 4.86 & 2.8 & 95 & 41.8 & 21.3 & 2.26 & 117 \\
\hline 6 & 35 & 25 & 40 & 5.05 & 2.9 & 85 & 42.2 & 23.9 & 2.19 & 118 \\
\hline 7 & 40 & 25 & 40 & 5.20 & 3.0 & 77 & 43.1 & 21.7 & 2.28 & 121 \\
\hline 8 & 50 & 25 & 40 & 4.69 & 2.7 & 70 & 45.0 & 20.4 & 2.25 & 125 \\
\hline 9 & 40 & 25 & 20 & 5.16 & 2.9 & 76 & 43.3 & 10.9 & 2.28 & 124 \\
\hline 10 & 40 & 25 & 60 & 4.41 & 2.5 & 64 & 41.2 & 20.9 & 2.16 & 117 \\
\hline 11 & 40 & 0 & 40 & 4.46 & 2.5 & 65 & 42.1 & 27.9 & 1.98 & 120 \\
\hline 12 & 40 & 50 & 40 & 5.36 & 3.1 & 80 & 43.6 & 16.9 & 2.38 & 121 \\
\hline 13 & 40 & 70 & 40 & 3.58 & 2.0 & 50 & 38.1 & 10.7 & 3.28 & 114 \\
\hline
\end{tabular}

${ }^{\mathrm{a}}$ Conditions: $\mathrm{Sc}, 21 \mu \mathrm{mol} ;\left[\mathrm{Ph}_{3} \mathrm{C}\right]\left[\mathrm{B}\left(\mathrm{C}_{6} \mathrm{~F}_{5}\right)_{4}\right], 21 \mu \mathrm{mol} ; P_{\text {ethylene }}=1 \mathrm{~atm}, 5 \mathrm{~min}$, unless otherwise noted ${ }^{\mathrm{b}} 10^{3} \mathrm{~kg} /(\mathrm{mol}-\mathrm{Sc} \cdot \mathrm{h} \cdot \mathrm{atm}) .{ }^{\mathrm{c}} \mathrm{DCPD}$ content, determined by ${ }^{1} \mathrm{H}$ NMR. ${ }^{\mathrm{d}}$ Determined by GPC in $\mathrm{CHCl}_{3}$ at 40 ${ }^{\circ} \mathrm{C}$ against polystyrene standard. ${ }^{\mathrm{e}}$ Measured by DSC. ${ }^{\mathrm{f}}$ Not determined. ${ }^{\mathrm{g}} P_{\text {ethylene }}=0 \mathrm{~atm}, 2 \mathrm{~h}$.

Table 9. Random terpolymerization of dicyclopentadiene (DCPD), ethylene (Et), and styrene (St) by $\mathbf{1} /\left[\mathrm{Ph}_{3} \mathrm{C}\right]\left[\mathrm{B}\left(\mathrm{C}_{6} \mathrm{~F}_{5}\right)_{4}\right]^{\mathrm{a}}$

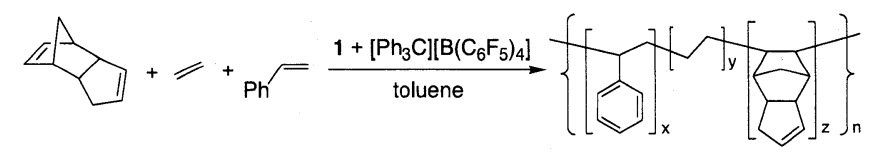

\begin{tabular}{|c|c|c|c|c|c|c|c|c|c|}
\hline entry & $\begin{array}{c}\text { Et } \\
(\mathrm{atm})\end{array}$ & $\begin{array}{l}\text { DCPD } \\
(\mathrm{mmol})\end{array}$ & $\begin{array}{c}\text { St } \\
(\mathrm{mmol})\end{array}$ & $\begin{array}{l}\text { yield } \\
(\mathrm{g})\end{array}$ & activity $^{b}$ & $\begin{array}{c}\text { composition } \\
(\mathrm{DCPD} / \mathrm{St} / \mathrm{Et} \text {, } \\
\mathrm{mol} \%)^{\mathrm{c}}\end{array}$ & $\begin{array}{c}M_{\mathrm{n}}{ }^{\mathrm{d}} \\
\left(10^{4}\right)\end{array}$ & $M_{\mathrm{w}} / M_{\mathrm{n}}{ }^{\mathrm{d}}$ & $\begin{array}{c}T_{\mathrm{g}}^{\mathrm{e}} \\
\left({ }^{\circ} \mathrm{C}\right)\end{array}$ \\
\hline 1 & 1 & 0 & 20 & 1.74 & 1.0 & $0 / 48.3 / 51.7$ & 28.2 & 1.52 & 115 \\
\hline 2 & 1 & 30 & 0 & 4.86 & 2.8 & $41.8 / 0 / 58.2$ & 21.3 & 2.26 & 117 \\
\hline $3^{\mathrm{f}}$ & 0 & 20 & 20 & trace & - & - & n.d. ${ }^{g}$ & n.d. & n.d. \\
\hline 4 & 1 & 5 & 20 & 2.13 & 1.2 & $4.9 / 46.4 / 48.7$ & 50.9 & 1.21 & 44 \\
\hline 5 & 1 & 10 & 20 & 2.25 & 1.3 & $8.8 / 42.7 / 48.5$ & 46.5 & 1.26 & 53 \\
\hline 6 & 1 & 20 & 20 & 0.83 & 0.5 & $9.5 / 43.2 / 47.3$ & 47.6 & 1.29 & 66 \\
\hline 7 & 1 & 30 & 30 & 0.96 & 0.6 & $6.9 / 57.3 / 35.8$ & 51.1 & 1.45 & 79 \\
\hline 8 & 1 & 30 & 20 & 1.18 & 0.7 & $12.4 / 44.5 / 43.1$ & 42.6 & 1.37 & 78 \\
\hline 9 & 1 & 30 & 10 & 1.94 & 1.1 & $22.2 / 15.4 / 62.4$ & 42.0 & 1.37 & 86 \\
\hline 10 & 1 & 30 & 5 & 3.22 & 1.8 & $26.4 / 4.0 / 69.6$ & 38.1 & 1.42 & 94 \\
\hline
\end{tabular}

${ }^{\text {a }}$ Conditions: 1, $21 \mu \mathrm{mol} ;\left[\mathrm{Ph}_{3} \mathrm{C}\right]\left[\mathrm{B}\left(\mathrm{C}_{6} \mathrm{~F}_{5}\right)_{4}\right], 21 \mu \mathrm{mol}$; toluene, $40 \mathrm{~mL}, 25^{\circ} \mathrm{C}, 5 \mathrm{~min}$, unless otherwise noted. ${ }^{\mathrm{b}} 10^{3} \mathrm{~kg} /(\mathrm{mol}-\mathrm{Sc} \cdot \mathrm{h} \cdot \mathrm{atm}) .{ }^{\mathrm{c}}$ Determined by ${ }^{1} \mathrm{H}$ NMR. ${ }^{\mathrm{d}}$ Determined by GPC in $1,2-\mathrm{C}_{6} \mathrm{H}_{4} \mathrm{Cl}_{2}$ at 120 ${ }^{\circ} \mathrm{C}$ against polystyrene standard. ${ }^{\mathrm{e}}$ Measured by DSC. ${ }^{\mathrm{f}}$ Toluene $10 \mathrm{~mL}, 2 \mathrm{~h} .{ }^{\mathrm{g}}$ Not determined. 
achieved was less than $85 \%{ }^{29}$

In contrast, half-sandwich rare earth metal catalysts showed excellent regio- and stereoselectivity for the polymerization of CHD, which afforded soluble, crystalline poly(CHD)s with the 1,4-linked cis-syndiotactic structure $(\text { Table } 10)^{30}$. The ion size of the central metals showed little influence on the activity and regio- and stereoselectivity of this polymerization system, and in most cases, perfect cis-1,4-selectivity $(100 \%)$ and high syndiotacticity ( $r r r r$ $70 \%$ ) were achieved at room temperature (Table 10, entries 1 and 6-10). At lower temperatures, a much higher syndiotacticity could be achieved (Table 10, entries 1-3). For example, when $1 /\left[\mathrm{Ph}_{3} \mathrm{C}\right]\left[\mathrm{B}\left(\mathrm{C}_{6} \mathrm{~F}_{5}\right)_{4}\right]$ was used as a catalyst, syndiotacticity of as high as $99 \%$ rrrr was achieved at $-10{ }^{\circ} \mathrm{C}$, yielding pure 1,4-linked cis-syndiotactic poly(CHD) (Table 10, entry 3 ). The cyclopentadienyl ancillary ligands of the half-sandwich rare earth metal complexes showed significant influence on both the catalytic activity and the selectivity. Among the scandium complexes 1-3, the $\mathrm{C}_{5} \mathrm{Me}_{5}$-ligated complex 3 showed the highest syndiotacticity $(99 \% \mathrm{rrrr}$ at room temperature) (Table 10, entry 5), while the $\mathrm{C}_{5} \mathrm{H}_{3}\left(\mathrm{SiMe}_{3}\right)_{2}$-supported complex 2 exhibited the highest activity albeit with poor regio- and stereoselectivity (Table 10, entry 4).

\subsection{Alternating Copolymerization of 1,3-Cyclohexadiene with Ethylene}

The scandium complexes $\mathbf{1}$ and $\mathbf{3}$ could also act as excellent catalyst precursors for the alternating 1,4-regioselective copolymerization of CHD with ethylene. The CHD-ethylene compolymers with CHD content of 40-50 mol\% could be easily prepared as shown in Table $11 .{ }^{30}$ This is in striking contrast with what was observed for the nickel- or titanium-based catalyst systems, in which the maximum incorporation of $\mathrm{CHD}$ in the CHD-ethylene copolymers was $12.3 \mathrm{~mol} \% .{ }^{29}{ }^{1} \mathrm{H}$ and ${ }^{13} \mathrm{C} \mathrm{NMR}$ analyses revealed that the copolymers obtained in the present system are alternating CHD-ethylene copolymers containing a small amount of isolated CHD units and a small amount of CHD-CHD sequences. The CHD units in these copolymers mainly adopt a cis-1,4-form. As far as we are aware, this is the first example of alternating copolymerization of CHD with ethylene.

Moreover, the syndiospecific, 1,4-selective copolymerization of CHD with styrene has also been achieved for the first time by use of such cationic half-sandwich rare earth metal catalysts. $^{30}$

\section{Polymerization and Copolymerization of Cyclohexene Oxide with Carbon Dioxide}

The copolymerization of $\mathrm{CO}_{2}$ with epoxides has received much current interest because it provides an environmentallyfriendly route to convert $\mathrm{CO}_{2}$ into biodegradable polymers and a pathway to a value-added product incorporating the ubiquitous $\mathrm{CO}_{2}$ molecule as a $\mathrm{Cl}$ feedstock. Since Inoue and co-workers first reported the copolymerization of $\mathrm{CO}_{2}$ with propylene oxide by use of a mixture of $\mathrm{ZnEt}_{2}$ and $\mathrm{H}_{2} \mathrm{O}$ in $1969,{ }^{31}$ extensive studies have been carried out in this area. ${ }^{32}$ For rare earth metal catalysts, however, only a few multiple-component heterogeneous systems were previously reported for the copolymerization of $\mathrm{CO}_{2}$ with epoxides. ${ }^{33} \mathrm{It}$ was recently found that neutral half-sandwich rare earth metal bis(alkyl) or dihydride ${ }^{34}$ complexes could act as a single-component catalyst system for the homopolymerization of epoxides and the copolymerizaion of epoxides with $\mathrm{CO}_{2}{ }^{5 \mathrm{~b}}$

As single-component catalysts, the neutral $\mathrm{C}_{5} \mathrm{Me}_{4} \mathrm{SiMe}_{3}-$ ligated rare earth metal bis(alkyl) complexes 1 (Sc), 4 (Y), 6 (Dy), and $10(\mathrm{Lu})$ were examined first for the ring-opening homopolymerization of cyclohexene oxide $(\mathrm{CHO})$ both in bulk and in toluene solution. ${ }^{5 \mathrm{~b}}$ The homopolymerization of

Table 10. Syndiospecific polymerization of 1,3-cyclohexadiene (CHD) by cationic half-sandwich scandium catalysts ${ }^{\mathrm{a}}$
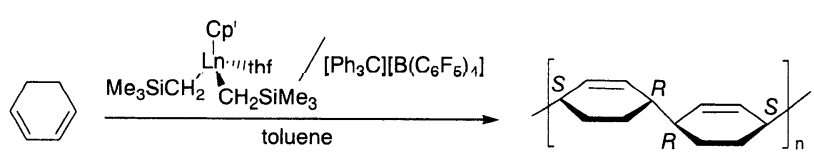

1,4-linked cis-syndiotactic

\begin{tabular}{cccccccccc}
\hline entry & $\begin{array}{c}\text { compd } \\
\text { (Ln) }\end{array}$ & $\begin{array}{c}\mathrm{T} \\
\left({ }^{\circ} \mathrm{C}\right)\end{array}$ & $\begin{array}{c}\text { Yield } \\
(\mathrm{g})\end{array}$ & $(\%)$ & cis-1,4- & $\begin{array}{c}\text { Syndiotacticity } \\
(\mathrm{brrr})\end{array}$ & $\begin{array}{c}M_{\mathrm{n}}{ }^{\mathrm{c}} \\
\left(10^{3}\right)\end{array}$ & $M_{\mathrm{w}} / M_{\mathrm{n}}{ }^{\mathrm{c}}$ & $\begin{array}{c}T_{\mathrm{m}}{ }^{\mathrm{d}} \\
\left({ }^{\circ} \mathrm{C}\right)\end{array}$ \\
\hline 1 & $\mathbf{1}(\mathrm{Sc})$ & 25 & 0.44 & 55 & 100 & 77 & 1.5 & 2.46 & 230 \\
$2^{\mathrm{e}}$ & $\mathbf{1}(\mathrm{Sc})$ & 0 & 0.14 & 18 & 100 & 93 & 2.5 & 2.12 & 225 \\
$3^{\mathrm{e}}$ & $\mathbf{1}(\mathrm{Sc})$ & -10 & 0.09 & 11 & 100 & 99 & 2.9 & 2.10 & 225 \\
4 & $\mathbf{2}(\mathrm{Sc})$ & 25 & 0.56 & 70 & 50 & - & 2.2 & 1.58 & 169 \\
5 & $\mathbf{3}(\mathrm{Sc})$ & 25 & 0.34 & 43 & 100 & 99 & 3.6 & 2.88 & 221 \\
6 & $\mathbf{4}(\mathrm{Y})$ & 25 & 0.30 & 38 & 100 & 75 & 3.7 & 3.42 & 230 \\
7 & $\mathbf{6}(\mathrm{Dy})$ & 25 & 0.41 & 51 & 100 & 73 & 2.9 & 3.55 & 230 \\
8 & $\mathbf{7}(\mathrm{Ho})$ & 25 & 0.40 & 50 & 100 & 72 & 3.4 & 3.46 & 231 \\
9 & $\mathbf{8}(\mathrm{Er})$ & 25 & 0.37 & 46 & 100 & 70 & 6.2 & 2.38 & 227 \\
10 & $\mathbf{1 0}(\mathrm{Lu})$ & 25 & 0.29 & 36 & 100 & 71 & 2.9 & 3.18 & 224
\end{tabular}

${ }^{\mathrm{a}}$ Conditions: $\mathrm{Ln}, 40 \mu \mathrm{mol} ;\left[\mathrm{Ph}_{3} \mathrm{C}\right]\left[\mathrm{B}\left(\mathrm{C}_{6} \mathrm{~F}_{5}\right)_{4}\right], 40 \mu \mathrm{mol}$; $\mathrm{CHD}, 10 \mathrm{mmol}$; toluene, $5 \mathrm{~mL} ; 2{ }^{\circ} \mathrm{C}, 3 \mathrm{~h}$, unless otherwise noted ${ }^{\mathrm{b}}$ Determined by ${ }^{1} \mathrm{H},{ }^{13} \mathrm{C}$ NMR. ${ }^{\mathrm{c}}$ Determined by GPC in $1,2-\mathrm{C}_{6} \mathrm{H}_{4} \mathrm{Cl}_{2}$ at $120^{\circ} \mathrm{C}$ using polystyrene standard. ${ }^{\mathrm{d}}$ Measured by DSC. ${ }^{\mathrm{e}}$ Reaction time: $12 \mathrm{~h}$. 
Table 11. Alternating copolymerization of ethylene with 1,3-cyclohexadiene (CHD) by cationic half-sandwich scandium catalysts ${ }^{\mathrm{a}}$

\begin{tabular}{|c|c|c|c|c|c|c|c|c|}
\hline entry & compd & $\begin{array}{l}\text { CHD } \\
(\mathrm{mmol})\end{array}$ & $\begin{array}{l}\text { yield } \\
(\mathrm{g})\end{array}$ & activity $^{b}$ & $\begin{array}{c}\text { CHD cont }{ }^{c} \\
(\mathrm{~mol} \%)\end{array}$ & $\begin{array}{l}M_{\mathrm{n}}{ }^{d} \\
\times 10^{-3}\end{array}$ & $M_{\mathrm{w}} / M_{\mathrm{n}}{ }^{d}$ & $\begin{array}{l}T_{\mathrm{m}}{ }^{e} \\
\left({ }^{\circ} \mathrm{C}\right)\end{array}$ \\
\hline 1 & $1(\mathrm{Sc})$ & 7.5 & 0.35 & 105 & 39 & 44.0 & 1.37 & 126 \\
\hline 2 & $\mathbf{1}(\mathrm{Sc})$ & 10.0 & 0.29 & 87 & 42 & 33.8 & 1.36 & 126 \\
\hline 3 & $1(\mathrm{Sc})$ & 12.5 & 0.15 & 45 & 48 & 27.1 & 1.31 & 124 \\
\hline 4 & $\mathbf{1}(\mathrm{Sc})$ & 15.0 & 0.08 & 24 & 51 & 2.5 & 1.67 & 126 \\
\hline 5 & $3(\mathrm{Sc})$ & 10.0 & 0.69 & 207 & 40 & 27.6 & 2.21 & 123 \\
\hline
\end{tabular}

${ }^{a}$ Conditions: Ln, $40 \mu \mathrm{mol} ;\left[\mathrm{Ph}_{3} \mathrm{C}\right]\left[\mathrm{B}\left(\mathrm{C}_{6} \mathrm{~F}_{5}\right)_{4}\right], 40 \mu \mathrm{mol}$; toluene, $20 \mathrm{~mL} ; 25{ }^{\circ} \mathrm{C} ; 5$ min. ${ }^{b}$ Given in kg polymer/(mol Ln'h.atm). ${ }^{c}$ Determined by ${ }^{1} \mathrm{H}$ NMR. ${ }^{d}$ Determined by GPC in $1,2-\mathrm{C}_{6} \mathrm{H}_{4} \mathrm{Cl}_{2}$ at $120{ }^{\circ} \mathrm{C}$ using polystyrene standard. ${ }^{e}$ Measured by DSC.

$\mathrm{CHO}$ in bulk took place much more rapidly than that in solution and afforded in high yields the corresponding polyether with $M_{\mathrm{n}}=(30-50) \times 10^{3}$ and $M_{\mathrm{w}} / M_{\mathrm{n}} \cong 2$ in most cases (Table 12). In toluene, the scandium complex 1 showed a much higher activity than other metal complexes $4,6,10$ (Table 12, entries 1-4), but in bulk polymerization, the difference in activity among these complexes was not so obvious (Table 12, entries 5-10).

The copolymerization of $\mathrm{CHO}$ with $\mathrm{CO}_{2}$ could also be achieved by use of the neutral half-sandwich rare earth metal bis(alkyl) complexes. Some representative results are shown in Table 13. Under appropriate conditions, the Y (4), Dy (6), and $\mathrm{Lu}(\mathbf{1 0})$ complexes all yielded the corresponding alternating copolymers containing high carbonate linkages (90-99\%). In contrast, the Sc alkyl complex 1 gave a polymer containing high ether linkages (carbonate linkages $=23 \%$ ) under similar conditions (Table 13 entry 1), probably due to its higher activity for $\mathrm{CHO}$ homopolymerization.

To gain insight into the mechanistic aspects of the
$\mathrm{CHO} / \mathrm{CO}_{2}$ copolymerization reactions, isolation and structural characterization of some reaction intermediates were attempted. In the reactions of the bis(alkyl) complexes $\mathbf{1}, \mathbf{4}$, and 10 with $\mathrm{CO}_{2}$, the $\mathrm{CO}_{2}$ insertion reaction took place very rapidly at both of the two alkyl groups, which finished within a few minutes even at low temperature under 1 atm of $\mathrm{CO}_{2}$ (Scheme 5). Each alkyl group reacted with one molecule of $\mathrm{CO}_{2}$ to yield the corresponding carboxylate complexes $\left[\left(\mathrm{C}_{5} \mathrm{Me}_{4} \mathrm{SiMe}_{3}\right) \mathrm{Ln}\left(\mu-\eta^{1}: \eta^{1}-\mathrm{O}_{2} \mathrm{CCH}_{2} \mathrm{SiMe}_{3}\right)_{2}\right]_{2}(\mathrm{Ln}=\mathrm{Sc}(\mathbf{1 1})$, $\mathrm{Y}(\mathbf{1 2}), \mathrm{Lu}(\mathbf{1 3}))$, in almost quantitative yields. Complexes 11-13 are isostructural and isomorphous, and adopt a dimeric structure through the carboxylate bridges. The $\mathrm{X}$-ray structure of the Y complex $\mathbf{1 2}$ is shown in Figure 3. The isolated binuclear carboxylate complexes $\mathbf{3 a}, \mathbf{b}$ also showed moderate activity for the alternating copolymerization of $\mathrm{CHO}$ and $\mathrm{CO}_{2}$, which thus constituted a rare example of a well-defined, catalytically active carboxylate intermediate that was isolated directly from the reaction of a true catalyst system. Since the reaction of the alkyl complexes $(\mathbf{1}, \mathbf{4}, \mathbf{6}, \mathbf{1 0})$

Table 12. Ring-opening polymerization of cyclohexene oxide by neutral half-sandwich scandium catalysts ${ }^{\mathrm{a}}$

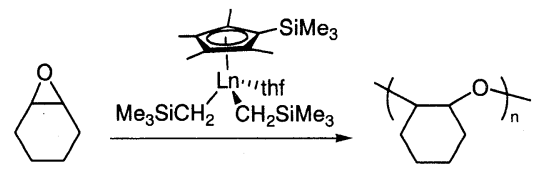

\begin{tabular}{ccccccc}
\hline entry & $\begin{array}{c}\text { compd } \\
(\mathrm{Ln})\end{array}$ & $\begin{array}{c}\text { time } \\
(\mathrm{h})\end{array}$ & $\begin{array}{c}\text { toluene } \\
(\mathrm{mL})\end{array}$ & $\begin{array}{c}\text { yield } \\
(\%)\end{array}$ & $\begin{array}{c}M_{\mathrm{n}}{ }^{\mathrm{b}} \\
\left(10^{3}\right)\end{array}$ & $M_{\mathrm{w}} / M_{\mathrm{n}}{ }^{\mathrm{b}}$ \\
\hline 1 & $\mathbf{1}(\mathrm{Sc})$ & 6 & 2 & 39.8 & 147.0 & 2.38 \\
2 & $\mathbf{4}(\mathrm{Y})$ & 6 & 2 & 15.0 & 38.0 & 2.01 \\
3 & $\mathbf{6}(\mathrm{Dy})$ & 6 & 2 & 12.5 & 21.7 & 1.79 \\
4 & $\mathbf{1 0}(\mathrm{Lu})$ & 6 & 2 & 23.0 & 41.0 & 2.00 \\
5 & $\mathbf{1}(\mathrm{Sc})$ & 3 & 0 & 85.3 & 50.8 & 2.89 \\
6 & $\mathbf{4}(\mathrm{Y})$ & 3 & 0 & 82.7 & 45.0 & 2.06 \\
7 & $\mathbf{6}(\mathrm{Dy})$ & 3 & 0 & 71.7 & 30.6 & 2.27 \\
8 & $\mathbf{1 0}(\mathrm{Lu})$ & 3 & 0 & 84.4 & 54.3 & 2.23 \\
\hline
\end{tabular}

${ }^{a}$ Conditions: $\mathrm{Ln}, 0.063 \mathrm{mmol}$; CHO, $25.2 \mathrm{mmol}$; $\mathrm{rt} .{ }^{\mathrm{b}}$ Determined by GPC in THF at $40{ }^{\circ} \mathrm{C}$ against polystyrene standard. 
Table 13. Alternating copolymerization of cyclohexene oxide with $\mathrm{CO}_{2}$ by neutral half-sandwich scandium catalysts

\begin{tabular}{|c|c|c|c|c|c|c|c|c|c|}
\hline entry & $\begin{array}{l}\text { compd } \\
(\mathrm{Ln})\end{array}$ & $\begin{array}{l}\text { [compd] } \\
(\mathrm{mmol} / \mathrm{L})\end{array}$ & $\begin{array}{l}{[\mathrm{CHO}]} \\
(\mathrm{mol} / \mathrm{L})\end{array}$ & $\begin{array}{c}\mathrm{T} \\
\left({ }^{\circ} \mathrm{C}\right)\end{array}$ & $\mathrm{TON}^{\mathrm{b}}$ & $\mathrm{TOF}^{\mathrm{c}}$ & $\begin{array}{l}M_{\mathrm{n}}{ }^{\mathrm{d}} \\
\left(10^{3}\right)\end{array}$ & $M_{\mathrm{w}} / M_{\mathrm{n}}^{\mathrm{d}}$ & $\begin{array}{c}\text { carbonate } \\
\text { linkages }^{\mathrm{e}} \\
(\%)\end{array}$ \\
\hline 1 & $1(\mathrm{Sc})$ & 16.3 & 6.5 & 70 & 13.6 & 567 & 8.4 & 3.68 & 23 \\
\hline 2 & $4(Y)$ & 16.3 & 6.5 & 70 & 24.0 & 1000 & 19.1 & 4.30 & 94 \\
\hline 3 & 6 (Dy) & 16.3 & 6.5 & 70 & 17.2 & 716 & 14.5 & 3.99 & 93 \\
\hline 4 & $10(\mathrm{Lu})$ & 16.3 & 6.5 & 70 & 30.0 & 1250 & 23.0 & 4.03 & 92 \\
\hline 5 & $10(\mathrm{Lu})$ & 6.1 & 5.02 & 70 & 6.7 & 278 & n.d. ${ }^{f}$ & n.d. & 90 \\
\hline 6 & $10(\mathrm{Lu})$ & 19.7 & 5.02 & 70 & 27.5 & 1146 & 22.1 & 4.50 & 92 \\
\hline 7 & $10(\mathrm{Lu})$ & 32.0 & 5.02 & 70 & 20.5 & 854 & 18.1 & 4.11 & 90 \\
\hline $8^{g}$ & $10(\mathrm{Lu})$ & 12.3 & 3.78 & 70 & 18.9 & 395 & 16.8 & 2.45 & 97 \\
\hline 9 & $10(\mathrm{Lu})$ & 12.3 & 5.02 & 70 & 31.0 & 1292 & 21.1 & 5.62 & 94 \\
\hline 10 & $10(\mathrm{Lu})$ & 12.3 & 6.50 & 70 & 31.2 & 1300 & 18.1 & 5.21 & 91 \\
\hline 11 & $10(\mathrm{Lu})$ & 12.3 & 8.00 & 70 & 32.4 & 1350 & 16.9 & 4.52 & 72 \\
\hline 12 & $10(\mathrm{Lu})$ & 12.3 & 5.02 & 50 & 15.0 & 625 & 12.6 & 2.46 & 92 \\
\hline 13 & $10(\mathrm{Lu})$ & 12.3 & 5.02 & 90 & 44.0 & 1833 & 25.9 & 4.96 & 95 \\
\hline 14 & $10(\mathrm{Lu})$ & 12.3 & 5.02 & 110 & 48.0 & 2000 & 23.7 & 6.03 & 97 \\
\hline 15 & $10(\mathrm{Lu})$ & 12.3 & 5.02 & 130 & 46.0 & 1917 & 20.1 & 6.81 & 95 \\
\hline
\end{tabular}

${ }^{\mathrm{a}}$ Conditions: $P_{\mathrm{CO} 2}=12 \mathrm{~atm}, 24 \mathrm{~h}$, in toluene. ${ }^{b} \mathrm{TON}=\mathrm{kg} /(\mathrm{mol}-\mathrm{Ln}) .{ }^{\mathrm{c}} \mathrm{TOF}=\mathrm{g} /(\mathrm{mol}-\mathrm{Ln} \cdot \mathrm{h}) .{ }^{\mathrm{d}}$ Determined by GPC in THF at $40{ }^{\circ} \mathrm{C}$ against polystyrene standard. ${ }^{e}$ Determined by ${ }^{1} \mathrm{H}$ NMR. ${ }^{f}$ Not determined. ${ }^{\mathrm{g}}$ Reaction time: $48 \mathrm{~h}$.

with $\mathrm{CO}_{2}$ was much faster than that with $\mathrm{CHO}$ in toluene, the $\mathrm{CHO} / \mathrm{CO}_{2}$ copolymerization in the present systems must be initiated by insertion of $\mathrm{CO}_{2}$ into a $\mathrm{Ln}-\mathrm{CH}_{2} \mathrm{SiMe}_{3}$ bond, followed by nucleophilic attack of the resulting carboxylate species to $\mathrm{CHO}$. To form an alternating copolymer, the insertion of $\mathrm{CO}_{2}$ into the $\mathrm{Ln}-\mathrm{O}(\mathrm{CHO})$ bond should be faster than that of $\mathrm{CHO}$.

Scheme 5. Stoichiometric reaction of $\mathrm{CO}_{2}$ with half-sandwich rare earth metal bis(alkyl) complexes

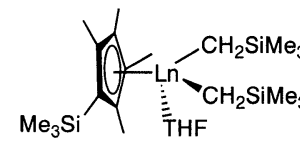

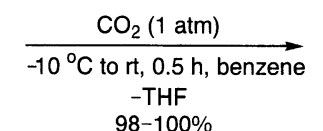

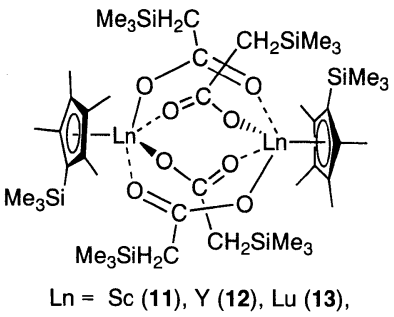

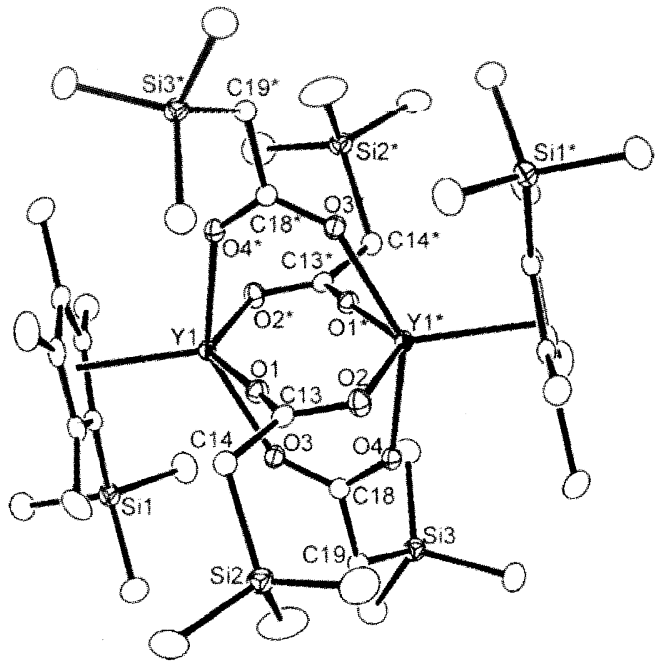

Figure 3. ORTEP drawing of $\mathbf{1 2}$.

\section{Conclusion}

The cationic half-sandwich rare earth metal alkyl species, generated by reaction of the bis(alkyl) complexes $\mathrm{Cp} \operatorname{Ln}\left(\mathrm{CH}_{2} \mathrm{SiMe}_{3}\right)_{2}$ with 1 equiv of a borate compound such as $\left[\mathrm{Ph}_{3} \mathrm{C}\right]\left[\mathrm{B}\left(\mathrm{C}_{6} \mathrm{~F}_{5}\right)_{4}\right]$, can act as an excellent catalyst system for the regio- and stereospecific polymerization and copolymerization of various olefins, such as syndiospecific living 
polymerization of styrene, syndiospecific cis-1,4-polymerization of 1,3-hexadiene, syndiospecific copolymerization of styrene with ethylene, alternating copolymerization of ethylene with norbornene, or dicyclopentadiene, or 1,3-cyclohexadiene, random and block terpolymerization of ethylene, norbornene (or dicyclopentadiene), and styrene, etc. Most of these polymerization reactions are unique to the rare earth catalysts, and are difficult to be achieved by previously known catalyst systems. In addition, the neutral half-sandwich rare earth metal bis(alkyl) complexes can serve as a single-component catalyst for both the ring-opening homopolymerization of cyclohexene oxide and the alternating copolymerization of cyclohexene oxide with $\mathrm{CO}_{2}$. These results demonstrate well the high potential of organo rare earth metal complexes in polymerization catalysis.

\section{Acknowledgments}

The author whishes to thank all of his coworkers for their dedication to this work. Their names are shown in the references. Special thanks go to Dr. Xiaofang Li and Dr. Yunjie Luo not only for their scientific contribution to this work but also for their assistance in the preparation of this manuscript. This work was partly supported by a Grant-in-Aid for Scientific Research on Priority Areas (No. 14078224, "Reaction Control of Dynamic Complexes") from the Ministry of Education, Culture, Sports, Science and Technology of Japan.

\section{References}

1) (a) Hou, Z.; Wakatsuki, Y. "Science of Synthesis," ed by Noyori, R.; Imamoto, T. Thieme, Stuttgart, 2002, 2, 849. (b) Molander, G. A.; Romero, J. A. C. Chem. Rev., 2002, 102, 2161. (c) Ephritikhine, M. Chem. Rev., 1997, 97, 2193. (d) Yasuda, H.; Ihara, E. Bull. Chem. Soc. Jpn. 1997, 70, 1745. (e) Anwander, R. "Applied Homogeneous Catalysis with Organometallic Compounds," ed. by Cornils, B.; Hermann W. A. VCH, Weinheim, 1996, 2, 866. (f) Schumann, H.; Meese-Marktscheffel, J. A.; Esser, L. Chem. Rev., 1995, 95, 865. (g) Edelmann, F. T. "Comprehensive Organometallic Chemistry II," ed by Abel, E. W.; Stone, F. G. A.; Wilkinson, G.; Lappert, M. F. Pergamon, Oxford, 1995, 4, 11. (h) Schaverien, C. J. Adv. Organomet. Chem., 1994, 36, 283.

2) (a) Hou, Z.; Wakatsuki, Y. Coord. Chem. Rev. 2002, 231, 1. (b) Hou, Z.; Wakatsuki, Y. J. Organomet. Chem., 2002, 647, 61. (c) Arndt, S.; Okuda, J. Chem. Rev. 2002, 102, 1953. (d) Gromada, J.; Carpentier, J. F.; Mortreux, A. Coord. Chem. Rev. 2004, 248 , 397. (e) Nakayama, Y.; Yasuda, H. J. Organomet. Chem., 2004, 689, 4489.

3) (a) Piers, W. E.; Emslie, D. J. H. Coord. Chem. Rev. 2002, 233-234, 131. (b) Hou, Z. Bull. Chem. Soc. Jpn. 2003, 76, 2253.

4) (a) Luo, Y.; Baldamus, J.; Hou, Z. J. Am. Chem. Soc. 2004, 126, 13910. (b) Li, X.; Baldamus, J.; Hou, Z. Angew. Chem., Int. Ed. 2005, 44, 962.

5) (a) Tardif, O.; Nishiura, M.; Hou, Z. Organometallics 2003, 22, 1171. (b) Cui, D.; Nishiura, M.; Hou, Z. Macromolecules 2005, 38, 4089. (c) Hultzsch, K. C.; Spaniol, T. S.; Okuda, J. Angew. Chem. Int. Ed. 1999, 38, 227.

6) (a) Ishihara, N.; Seimiya, T.; Kuramoto, M.; Uoi, M. Macromolecules 1986, 19, 2464. (b) Ishihara, N.; Kuramoto, M.; Uoi, M. Macromolecules 1988, 21, 3356.

7) (a) Tomotsu, N; Ishihara, N.; Newman, T. H.; Malanga, M. T. J. Mol. Catal. A: Chem. 1998, 128, 167. (b) Malanga, M. Adv. Mater. 2000, 12, 1869.

8) Kirillov, E.; Lehmann, C. W.; Razavi, A.; Carpentier, J. F. J. Am. Chem. Soc. 2004, 126, 12240.

9) Coates, G. W. Chem. Rev. 2000, 100, 1223

10) (a) Voth, P.; Arndt, S.; Spaniol, T. P.; Okuda, J.; Ackerman, L. J.; Green, M. L. H. Organometallics 2003, 22, 65. (b) Luo, Y. J.; Yao, Y. M.; Shen, Q. Macromolecules 2002, 35, 8670. (c) Hultzsch, K. C.; Voth, P.; Beckerle, K.; Spaniol, T. P.; Okuda, J. Organometallics 2000, 19, 228. (d) Zhang, Y. G.; Hou, Z.; Wakatsuki, Y. Macromolecules 1999, 32, 939.

11) (a) McKnight, A. L.; Waymouth, R. M. Chem. Rev. 1998, 98,
2587 and references cited therein. (b) Chum, P. S.; Kruper, W. J.; Guest, M. J. Adv. Mater. 2000, 12, 1759. (c) Grassi, A.; Caprio, M.; Zambelli, A.; Bowen, D. E. Macromolecules 2000, 33, 8130. (d) Chu, P. P.; Tseng, H. S.; Chen, Y. P.; Yu, D. D. Polymer 2000, 41, 8271. (e) Caporaso, L.; Izzo, L.; Sisti, I.; Oliva, L. Macromolecules 2002, 35, 4866. (f) Nomura, K.; Okumura, H.; Komatsu, T.; Naga, N. Macromolecules 2002, 35, 5388. (g) Capacchione, C.; D'Acunzi, M.; Motta, O.; Oliva, L.; Proto, A.; Okuda, J. Macromol. Chem. Phys. 2004, 205, 370. (h) Noh, S. K.; Lee, M. J.; Kum, D. H.; Kim, K.; Lyoo, W. S.; Lee, D. H. J. Polym. Sci. Part A: Polym. Chem. 2004, 42, 1712. (i) Guo, N.; Li, L.; Marks, T. J. J. Am. Chem. Soc. 2004, 126, 6542.

12) (a) Zhang, Y. G.; Hou, Z. M.; Wakatsuki, Y. Macromolecules 1998 31, 8650. (b) Hou, Z. M.; Zhang, Y. G.; Tezuka, H.; Xie, P.; Tardif, O.; Koizumi, T.; Yamazaki, H.; Wakatsuki, Y. J. Am. Chem. Soc. 2000, 122, 10533. (c) Koo, K.; Fu, P. F.; Marks, T. J. Macromolecules 1999, 32, 981 .

13) Luo, Y.; Baldamus, J.; Nishiura, M.; Hou, Z. Manuscript in preparation.

14) Luo, Y.; Hou, Z. Manuscript in preparation.

15) (a) Ward, B. D.; Bellemin-Laponnaz, S.; Gade, L. H. Angew. Chem. Int. Ed. 2005, 44, 1668. (b) Tredget, C. S.; Bonnet, F; Cowley, A. R.; Mountford, P. Chem. Commun. 2005, 3301.

16) (a) Jeske, G.; Schock, L. E.; Swepston, P. N.; Schumann, H.; Marks, T. J. J. Am. Chem. Soc. 1985, 107, 8103. (b) Shapiro, P. J.; Bunel, E.; Schaefer, W. P.; Bercaw, J. E. Organometallics 1990, 9, 867. (c) Coughlin, E. B.; Bercaw, J. E. J. Am. Chem. Soc. 1992, 114, 7606. (d) Schaverien, C. J. Organometallics 1994, 13, 69. (e) Yasuda, H.; Ihara, E.; Yoshioka, S.; Nodono, M.; Morimoto, M.; Yamashita, M. Studies in Surface Science and Catalysis 1994, 89, 237. (f) Shapiro, P. J.; Cotter, W. D.; Schaefer, W. P.; Labinger, J. A.; Bercaw, J. E. J. Am. Chem. Soc. 1994, 116, 4623. (g) Yasuda, H.; Ihara, E. Macromol. Chem. Phys 1995, 196 2417. (h) Yasuda, H.; Ihara, E. Tetrahedron 1995, 51, 4563. (i) Ihara, E.; Nodono, M.; Yasuda, H.; Kanehisa, N.; Kai, Y. Macromol. Chem. Phys. 1996, 197, 1909. (j) Ihara, E.; Nodono, M.; Katsura, K.; Adachi, Y.; Yasuda, H.; Yamagashira, M.; Hashimoto, H.; Kanehisa, N.; Kai, Y. Organometallics 1998, 17, 3945. (k) Koo, K.; Fu, P. F.; Marks, T. J. Macromolecules 1999, 32, 981. (1) Desurmont, G.; Tokimitsu, T.; Yasuda, H. Macromolecules 2000, 33, 7679. (m) Ihara, E.; Yoshioka, S.; Furo, M.; Katsura, K.; Yasuda, H.; Mohri, S.; Kanehisa, N.; Kai, Y. Organometallics 2001, 20, 1752. (n) Yasuda, H.; Desurmont, G. Polym. Int. 2004, 53, 1017.

17) Homogeneous polymerization catalyst systems usually show no or negative "comonomer effect" in the copolymerization of ethylene with $\alpha$-olefins, although a positive "comonomer effect" was known in heterogeneous Ziegler-Natta catalysis. For examples, see: (a) Chien, J. C. W.; Nozaki, T. J. Polym. Sci., Part A: Polym. Chem. 1993, 31, 227. (b) Choo, T. N.; Waymouth, R. M. J. Am. Chem. Soc. 2002, 124, 4188. (c) Bruaseth, I; Rytter, E. Macromolecules 2003, 36, 3026. (d) Dankova, M.; Waymouth, R. M. Macromolecules 2003, 36, 3815. (e) Mahanthappa, M. K.; Cole, A. P.; Waymouth, R. M. Macromolecules 2004, 23, 836. (f) Hu, W. Q.; Sun, X. L.; Wang, C.; Gao, Y.; Tang, Y.; Shi, L. P.; Xia, W.; Sun, J.; Dai, H. L.; Li, X. Q.; Yao, X. L.; Wang, X. R. Organometallics 2004, 23, 1684. (g) Reybuck, S. E.; Waymouth, R. M. Macromolecules 2004, 37, 2342.

18) Kaminsky, W.; Bark, A.; Arndt, M. Makromol. Chem., Macromol. Symp. 1991, 47, 83.

19) (a) Ruchatz, D.; Fink, G. Macromolecules 1998, 31, 4669. (b) Lee, B. Y.; Kim, Y. H.; Won, Y. C.; Han, J. W.; Suh, W. S.; Lee, I. S.; Chung, Y. K.; Song, K. H. Organometallics 2002, 21, 1500. (c) McKnight, A. L.; Waymouth, R. M. Macromolecules 1999, 32, 2816. (d) Altamura, P.; Grassi, A. Macromolecules 2001, 34 , 9197. (e) Nomura, K.; Tsubota, M.; Fujiki, M. Macromolecules 2003, 36, 3797. (f) Tritto, I.; Marestin, C.; Boggioni, L.; Sacchi, M. C.; Brintzinger, H. -H.; Fetto, D. R. Macromolecules 2001, 34, 5770. (g) Yoshida, Y.; Saito, J.; Mitani, M.; Takagi, Y.; Matsui, S.; Ishii, S.; Nakano, T. S.; Kashiwa, N.; Fujita, T. Chem. Comm. 2002, 1298. (h) Benedikt, G. M.; Elce, E.; Goodall, B. L.; Kalamarides, H. A.; McIntosh, L. H.; Rhodes, L. F.; Selvy, K. T. Macromolecules 2002, 35, 8978. (i) Li, X. F.; Dai, K.; Ye, W. P.; Pan, L.; Li, Y. S. Organometallics 2004, 23, 1223.

20) Li, X.; Hou, Z. Macromolecules 2005, 38, 6767.

21) Li, X.; Hou, Z. unpublished results.

22) Sernetz, F.; Mülhaupt, R. J. Polym. Sci., Part A: Polym. Chem. $1997,35,2549$. 
23) (a) Suzuki, J.; Kino, Y.; Uozumi, T.; Sano, T.; Teranishi, T.; Jin, J.; Soga, K.; Shiono, T. J. Appl. Polym. Sci. 1999, 72, 103. (b) Simanke, A. G.; Mauler, R. S.; Galland, G. B. J. Polym. Sci., Part A: Polym. Chem. 2002, 40, 471. (c) Naga, N. J. Polym. Sci., Part A: Polym. Chem. 2005, 43, 1285.

24) (a) Lefebvre, G.; Dawans, F. J. Polym. Sci. 1964, A2, 3277. (b) Stücklen, H.; Thayer, H.; Willis, P. J. Am. Chem. Soc. 1940, 62, 1717.

25) (a) Lussi, H.; Braman, J. Helv. Chim. Acta 1967, 50, 1233. (b) Mango, L. A.; Lenz, R. W. Polym. Prepr. (Am. Chem. Soc., Polym. Chem. Div.) 1971, 12, 402. (c) Sharaby, Z.; Jagur-Grodzinski, J.; Martan, M.; Vofsi, D. J. Polym. Sci., Polym. Chem. Ed. 1982, 20, 901. (d) Francois, B.; Zhong, X. F. Makromol. Chem. 1990, 191, 2743. (e) Cassidy, P. E.; Marvel, C. S.; Ray, S. J. Polym. Sci. 1965, A3 1553. (f) Natori, I. Macromolecules 1997, 30, 3696. (g) Natori, I.; Inoue, S. Macromolecules 1998, 31, 982. (h) Natori, I.; Inoue, S. Macromolecules 1998, 31 , 4687. (i) Hong, K. L.; Mays, J. W. Macromolecules 2001, 34, 782. (j) Williamson, D. T.; Elman, J. F.; Madison, P. H.; Pasquale, A. J.; Long, T. E. Macromolecules 2001, 34, 2108. (k) Williamson, D. T.; Glass, T. E.; Long, T. E. Macromolecules 2001, 34, 6144. (1) Quirk, R. P.; You, F.; Wesdemiotis, C.; Arnould, M. A. Macromolecules 2004, 37, 1234.

26) (a) Frey, D. A.; Hasegawa, M.; Marvel, C. S. J. Polym. Sci., Part A: Polym. Chem. Ed. 1963, 1, 2057. (b) Lefebvre, G.; Dawans, F. J. Polym, Sci., Part A: Polym. Chem. Ed. 1964, 2, 3277.

27) (a) Marvel, C. S.; Hartzell, G. E. J. Am. Chem. Soc. 1959, 81, 448. (b) Yousufzi, A. H. K.; End, V.; Otsu, T. J. Polym. Sci., Polym. Chem. Ed. 1975, 13, 1601.

28) (a) Nakano, M.; Yao, Q.; Usuki, A.; Tanimura, S.; Matsuoka, T. Chem. Commun., 2000, 2207. (b) Po, R.; Santi, R.; Romano, A. M. J. Polym. Sci, Polym. Part A: Polym. Chem. 2000, 38, 3004. (c) Longo, P.; Freda, C.; Ballesteros, O. R.; Grisi, F. Macromol. Chem. Phys. 2001, 202, 409. (d) Tanimura, S.; Matsuoka, T.; Nakano, M.; Usuki, A. J. Polym. Sci, Polym. Part B: Polym. Phys. 2001, 39, 973.

29) Heiser, D. E.; Okuda, J.; Gambarotta, S.; Mülhaupt, R. Macromol. Chem. Phys. 2005, 206, 195.

30) Li, X.; Baldamus, J; Hou, Z. unpublished results.

31) Inoue, S.; Koinuma, H.; Tsuruta, T. J. Polym. Sci., Part B: Polym Phys. 1969, 7, 287.

32) For reviews on the copolymerization of epoxides and $\mathrm{CO}_{2}$, see: (a) Darensbourg, D. J.; Holtcamp, M. W. Coord. Chem. Rev. 1996, 153, 155. (b) Super, M.; Beckman, E. J. Macromol. Symp. 1998, 127, 89. (c) Darensbourg, D. J.; Mackiewicz, R. M; Phelps, A. L.; Billodeaux, D. R. Acc, Chem. Res. 2004, 37, 836. (d) Coates, G. W.; Moore, D. R. Angew. Chem. Int. Ed. 2004, 43, 6618.

33) (a) Chen, X.; Shen, Z.; Zhang, Y. Macromolecules 1991, 24, 5305. (b) Liu, B.; Zhao, X.; Wang, X.; Wang, F. J. Polym. Sci: Part A: Polym. Chem. 2001, 39, 2751. (c) Quan, Z.; Min, J.; Zhou, Q.; Xie, D.; Liu, J.; Wang, X.; Zhao, X.; Wang, F. Macromol. Symp. 2003, 195, 281. (d) Liu, B.; Zhao, X.; Wang, X.; Wang, F. Polymer 2003, 44, 1803. (e) Tan, C.-S.; Hsu, T.-J. Macromolecules 1997, 30, 3147. (f) Hsu, T.-J. Tan, C.-S. Polymer 2001, 42, 5143.

34) (a) Tardif, O.; Hashizume, D.; Hou, Z. J. Am. Chem. Soc. 2004, 126, 8080. (b) Cui, D.; Tardif, O.; Hou, Z. J. Am. Chem. Soc. 2004, 126, 1312. (c) Tardif, O.; Nishiura, M.; Hou, Z. Organometallics, 2003, 22, 1171.

\section{PROFILE}

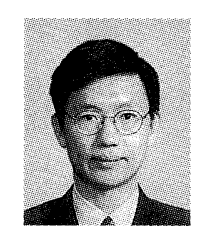

Zhaomin Hou is Chief Scientist, Director of Organometallic Chemistry Laboratory at RIKEN (The Institute of Physical and Chemical Research). He was born in Shandong Province, China, in 1961, and received his B. Sc. (1982) from University of Petroleum of China and his $\mathrm{Ph}$. D. degree (1989) from Kyushu University. After working as a postdoctoral fellow at RIKEN (1989-1991) and University of Windsor (1991-1992), he was appointed Research Scientist at RIKEN in 1993, Senior Scientist in 1997, and Chief Scientist, Director of Organometallic Chemistry Laboratory in 2002. He is Visiting Professor at Saitama University (2003-present), Peking University (2004-present), and University of Louis Pasteur (2005). He received Japan Society of Coordination Chemistry Award for Young Scientists in 1996, Rare Earth Society of Japan Award for Young Scientists in 1997, and Progress Award in Synthetic Organic Chemistry, Japan in 2000. His research interests are in the areas of organometallic chemistry, catalysis, and polymer chemistry. 